\title{
The Walker 256 Breast Cancer Cell- Induced Bone Pain Model in Rats
}

\section{OPEN ACCESS}

Edited by:

Ajay Sharma,

Chapman University, USA

Reviewed by:

Guilherme Lucas,

University of São Paulo, Brazil

Dan Cacsire Castillo-Tong,

Medical University of Vienna, Austria

Roberto Jose Fajardo,

University of Texas Health Science

Center at San Antonio, USA

*Correspondence:

Maree T. Smith

maree.smith@uq.edu.au

Specialty section:

This article was submitted to

Experimental Pharmacology and Drug

Discovery,

a section of the journal

Frontiers in Pharmacology

Received: 22 June 2016

Accepted: 18 August 2016

Published: 31 August 2016

Citation:

Shenoy PA, Kuo A, Vetter I and Smith MT (2016) The Walker 256 Breast Cancer Cell- Induced Bone Pain Model in Rats.

Front. Pharmacol. 7:286.

doi: 10.3389/fphar.2016.00286

\author{
Priyank A. Shenoy ${ }^{1,2}$, Andy Kuo ${ }^{2}$, Irina Vetter ${ }^{3,4}$ and Maree T. Smith ${ }^{2,4 *}$ \\ ${ }^{1}$ School of Biomedical Sciences, The University of Queensland, Brisbane, QLD, Australia, ${ }^{2}$ Centre for Integrated Preclinical \\ Drug Development, The University of Queensland, Brisbane, QLD, Australia, ${ }^{3}$ Institute for Molecular Bioscience, The \\ University of Queensland, Brisbane, QLD, Australia, ${ }^{4}$ School of Pharmacy, The University of Queensland, Brisbane, QLD, \\ Australia
}

The majority of patients with terminal breast cancer show signs of bone metastasis, the most common cause of pain in cancer. Clinically available drug treatment options for the relief of cancer-associated bone pain are limited due to either inadequate pain relief and/or dose-limiting side-effects. One of the major hurdles in understanding the mechanism by which breast cancer causes pain after metastasis to the bones is the lack of suitable preclinical models. Until the late twentieth century, all animal models of cancer induced bone pain involved systemic injection of cancer cells into animals, which caused severe deterioration of animal health due to widespread metastasis. In this mini-review we have discussed details of a recently developed and highly efficient preclinical model of breast cancer induced bone pain: Walker 256 cancer cell- induced bone pain in rats. The model involves direct localized injection of cancer cells into a single tibia in rats, which avoids widespread metastasis of cancer cells and hence animals maintain good health throughout the experimental period. This model closely mimics the human pathophysiology of breast cancer induced bone pain and has great potential to aid in the process of drug discovery for treating this intractable pain condition.

\section{Keywords: breast cancer, metastasis, bone pain, Walker 256 cell, rat model}

\section{INTRODUCTION}

The most common cause of pain in cancer arises from bone metastasis, and around $73 \%$ of patients with terminal breast cancer exhibit indications of bone metastases (Coleman, 2006; Currie et al., 2013; Bu et al., 2014). Of these, 75\% suffer severe bone pain and pathological fractures (Ibrahim et al., 2013). This is in contrast to primary breast tumors in the tissue of origin that cause very little or no pain at all (Lozano-Ondoua et al., 2013). Clinically, nonsteroidal anti-inflammatory drugs are the mainstay of treatment, often in combination with strong opioid analgesics, radiotherapy in the initial stages of metastasis, and adjuvant agents that inhibit osteoclast activity such as bisphosphonates and denosumab (Mantyh et al., 2002; Colvin and Fallon, 2008; Fallon et al., 2016; Fernandes et al., 2016). The principal challenge in understanding the pathophysiological mechanisms of cancer-induced bone pain (CIBP) is the development of an animal model which has characteristics in common with that of human CIBP (Slosky et al., 2015). It is only recently that preclinical studies have begun to determine how metastatic cancers may interact with the bone microenvironment resulting in pain

Abbreviations: CIBP, cancer- induced bone pain; ITI, intra-tibial injection. 
(Lozano-Ondoua et al., 2013). Until the late twentieth century, all animal models of CIBP relied on systemic injection of carcinoma cells, which resulted in poor animal health because of metastases in vital organs such as the liver, lungs, brain, and multiple sites in bone (Urch, 2004; Simmons et al., 2015). Subsequently, the more efficient method of local infusion of cancer cells into a single bone was developed, thereby avoiding systemic spread of cancer cells and the maintenance of good general animal health (Schwei et al., 1999). Although, multiple breast cancer cell lines have been used to induce bone tumors in rats and mice, the focus of this minireview is confined to research in which Walker 256 rat breast cancer cells have been used to induce bone pain in rats.

\section{RAT AS THE SPECIES OF CHOICE}

Rats and mice are the most commonly used animal species for pain research (Walker et al., 1999), with rats being superior to mice in many practical respects (Wilson and Mogil, 2001; Mogil, 2009). The advantage of mouse pain models is the availability of transgenic mice for dissecting pathophysiological mechanisms (Mogil and Grisel, 1998) and mouse models of breast cancer might recapitulate key aspects of human breast cancer including poor immunogenicity and high metastatic potential (Hahn et al., 2006). However, the main disadvantage of mice is their small size, making direct injection of tumor cells into the bone technically challenging (Pacharinsak and Beitz, 2008). By contrast, rat models are considered very suitable for efficacy assessment of therapeutic interventions for the treatment of breast CIBP (Medhurst et al., 2002). The model using Walker 256 cells can be induced in both sexes of rats (Liu et al., 2010, 2011) and different rat strains are compatible with these cells (Earle, 1935; Jensen and Muntzing, 1970). Stage of the estrous cycle in female rats does not alter the development of CIBP (Zhu G. Q. et al., 2014).

\section{SUITABILITY OF WALKER 256 CELLS}

The Walker tumor was first discovered in the breast of a pregnant albino rat (Rattus norvegicus) in 1928 by Dr. George Walker in Baltimore and it is regarded as a carcinosarcoma (McEuen and Thomson, 1933; Simpkins et al., 1991). It is one of the most widely used transplantable tumors in experimental research (Justice, 1985; Brigatte et al., 2007; Fan et al., 2016; Gambeta et al., 2016; Gao et al., 2016; Sroka et al., 2016; Wu M. et al., 2016). Indeed, these cells are one of the most preferred cell lines because of the ease with which they can be standardized, maintained and propagated in vitro, as well as their extensive use in vivo since 1937 (Michaelson and Orcutt, 1957; Brigatte et al., 2016; Galuppo et al., 2016; Pigatto et al., 2016; Trashkov et al., 2016; Yalovenko et al., 2016).

Walker 256 cells cause significant bone resorption and increase skeletal fragility at the site of implantation in rats (Kurth et al., 2000), consistent with the phenotype observed in breast cancer patients with bone metastasis (Shih et al., 2004). In addition to being a reproducible method for inducing skeletal metastasis (Blouin et al., 2005; Mao-Ying et al., 2006; Badraoui et al., 2009), this model mimics key features of human breast CIBP, including pharmacological profile (Mao-Ying et al., 2006, 2012; Cao et al., 2010). Walker 256 cells can be used in a variety of rat strains (Hang et al., 2015; Lu et al., 2015) because these cells produce uniformly rapid growth, show very little regression, and are readily adaptable (Lewis et al., 2013; Oliveira and GomesMarcondes, 2016).

Growth of Walker 256 cells in the form of tumor is practically independent of the age and weight of the animals at the time of their inoculation (Walpole, 1951). Another advantage is that after unilateral intra-tibial injection (ITI), tumor cells do not metastasize to the contralateral tibia during the experimental period and they only cause structural degradation of bones in the ipsilateral limb but not the contralateral limb (Kurth et al., 2001, 2002). They also generally do not metastasize to highly perfused organs such as the lungs (Brigatte et al., 2007), in contrast to other cell lines such as the 13762 rat mammary carcinoma cell line or the c-SST2 rat mammary carcinoma cell line, which spontaneously metastasize (Blouin et al., 2005).

Although, many scientists tend to presume that tumor cell lines behave indefinitely in a uniform manner (Lewis et al., 2013), changes may be induced by factors such as extended in vitro growth time, high passage number and cross contamination with other cell lines (Sacchi et al., 1984; Chang-Liu and Woloschak, 1997; Buehring et al., 2004; Liscovitch and Ravid, 2007). Immortalized cancer cell lines may also evolve in vivo over time in the animal models in which cancer is induced (Poste et al., 1982b). Various heterogeneous subpopulations of tumor cells within a tumor mass possess diverse metastatic potential and different propensities for metastasis to various organs (Fidler, 1978; Poste et al., 1982a). Similarly, immortalized Walker 256 cancer cell lines from different cell banks may possess diverse characteristics and behavior in vivo despite the fact that these cell lines are from rat origin and are without contamination (Lewis et al., 2013). In general, cell lines may be authenticated by short tandem repeat (STR) profiling of the microsatellite regions of DNA (Nims et al., 2010). However, as there is no reference DNA profile of the Walker 256 cell line (Lewis et al., 2013), researchers typically procure cells of a defined passage number from reputable cell banks. To minimize within- and between- laboratory variability in the use of these cells in vivo, it is important that cultured cells are banked and frozen at early passages, and that culture conditions including growth media, temperature, humidity and exposure to drugs are standardized (Marx, 2014).

\section{GENERAL METHODOLOGY}

Although there are minor between-laboratory variations, the general method for induction of breast CIBP in rats has several aspects in common. The procedure generally involves making an incision to the skin and muscle around the knee joint of the anesthetized rat and injecting cancer cells into the tibial bone, followed by sealing of the drilled hole with bone wax, suturing of the wound and close monitoring of animals during post-surgical recovery (Mao-Ying et al., 2006). Cells can also be 
injected in the femur (Gui et al., 2013, 2015). Small differences in the number of injected Walker 256 cancer cells due to experimental errors typically have a minimal effect on the study outcome (Kurth et al., 2001). The physical process for injection of Walker 256 cells into the medullary canal of the bone does not impact the study outcome adversely as emphasized by the normal fibroblastic healing response around the drilled hole of injected bone (Kurth et al., 2002; Mao-Ying et al., 2006). Although outflow of cells during the injection process can be a common occurrence associated with the model, the syringe can be left in place inside the medullary canal of the bone for an additional 1 or 2 min to avoid leakage of cells along the injection track (Mao-Ying et al., 2006; Yu et al., 2009; Miao et al., 2010; Dong et al., 2011; Hu S. et al., 2012).

\section{TIME FRAME FOR DEVELOPMENT OF PAIN BEHAVIORS AND ANALGESIC EFFICACY TESTING}

One of the most important and critical factors in the study of pain behavior and extent of bone destruction in this model is the timing of observations post-surgery (Qiu et al., 2012). Large tumors can develop in just a few days (Justice, 1985). However, the time period for development of pain behaviors may vary between studies based upon factors such as cell invasiveness and sex of the experimental animals (Wang et al., 2011). Pain behavior due to the surgical process may be evoked in the ipsilateral (injected) hind paws if the animals are tested immediately after the inoculation surgery (Lan et al., 2010; Dong et al., 2011). Hence a recovery period of 2-3 days post-surgery must be provided for the animals (Wang et al., 2011). For the purposes of studying different mechanisms of breast CIBP and for efficacy profiling of molecules with potential to be developed as novel analgesic agents, it is best to avoid extending the model beyond 20-25 days post-surgery (Mao-Ying et al., 2006; Yu et al., 2009; Cao et al., 2010; Tong et al., 2010; Hang et al., 2014) due to overall poor animal health and ethical concerns (Kurth et al., 2001). In particular, prolonged observation times may be associated with more complex pathophysiology arising from systemic metastasis due to severe osteolysis (Qiu et al., 2012). Hence, the period between days 6 and 18 post-ITI is typically chosen for investigation of breast CIBP mechanisms and the efficacy testing of novel compounds with potential as analgesic agents (Wang et al., 2011; Hu et al., 2012a; Wang L. N. et al., 2012b).

\section{NATURE OF PAIN MANIFESTATION}

In Walker 256 cell-CIBP, up-regulated expression and release of pro-inflammatory mediators including prostaglandin E2 (PGE2), nerve growth factor (NGF), and proinflammatory cytokines including interleukin (IL)-1 $\beta$, IL-6 and tumor necrosis factor- $\alpha$ (TNF- $\alpha$ ) in the spinal cord and dorsal root ganglia contributes to the pathogenesis of bone pain in rats (Cao et al., 2010; Lan et al., 2010; Liu et al., 2010; Dong et al., 2011; Mao-Ying et al., 2012; Yao et al., 2016; Zhu et al., 2016). Hence, neuroinflammation is an important pathogenic characteristic of this model (Hu S. et al., 2012; Song et al., 2015).

Similar to the clinical situation, Walker 256 cell-CIBP manifests as spontaneous pain, hyperalgesia, allodynia as well as ambulatory pain, the severity of which largely depends upon the number of inoculated cells, but can also be affected by other experimental factors including cell origin as well as strain or sex of the animals used (Mao-Ying et al., 2006; Liu et al., 2010). Similarly, hind paw hypersensitivity induced by ITI with Walker 256 cells may be either unilateral (Liu et al., 2010; Tong et al., 2010; Dong et al., 2011; Wang J. et al., 2012; Wang L. N. et al., 2012b) or bilateral (Mao-Ying et al., 2006, 2012; Zhao et al., 2013; Li et al., 2014). Peripheral mechanisms including circulating factors and transmedian sprouting, or central mechanisms such as signaling via commissural interneurons in the spinal cord and brain stem may underpin unilateral injuryinduced contralateral mirror effects (Koltzenburg et al., 1999). This mirror image effect may also be correlated with spinal glia cell activation, proinflammatory cytokine production, and morphological changes within the local nerve, suggesting the involvement of glia (Chacur et al., 2001). The mirror image pain behavior induced in the contralateral hind paw in this model may be observed when the tumors are in the advanced stage (Miao et al., 2010; Zhao et al., 2013; Li et al., 2014) Typically though, contralateral pain behaviors are of reduced intensity compared with the ipsilateral hind paw (Miao et al., 2010).

Thermal and mechanical pain behaviors are underpinned by different mechanisms (Paqueron et al., 2003; Wang J. et al., 2012). Cutaneous nociceptors are particularly sensitized by thermal stimuli and nociceptors present in deep somatic tissues such as joints and muscle exhibit pronounced sensitization to mechanical stimuli (Schaible, 2007). Although, thermal hyperalgesia has been reported in this model (Liu et al., 2011; Duan et al., 2012; Wang J. et al., 2012), there are several studies in which hindpaw hypersensitivity to an applied noxious heat stimulus is not observed in rats following a unilateral ITI of Walker 256 cells (Mao-Ying et al., 2006, 2012; Yao et al., 2008; Miao et al., 2010; Wang et al., 2011). Again, these differences may be attributed to various factors including between-vendor differences in animals and cancer cell-related factors. For this reason, thermal hyperalgesia is not typically used as a pain behavioral endpoint in this model (Yu et al., 2009; Cao et al., 2010; Tong et al., 2010; Zhao et al., 2010; Dong et al., 2011). A between-study comparison of Walker 256 cell- CIBP rat model is presented in Table 1.

\section{REGRESSION OF TUMOR AND RESOLUTION OF PAIN}

Similar to the well-known human scenario of breast cancer regression (Lewison, 1976; Hutter, 1982; Burnside et al., 2006; Barry, 2009; Onuigbo, 2012), Walker 256 breast cancer cells may also potentially transform into a regressive variant in vivo (Guimarães et al., 2010) resulting in complete regression if the study is prolonged (Jensen and Muntzing, 1970; Cavalcanti et al., 2003; Schanoski et al., 2004). The mechanisms underlying spontaneous regression are not entirely clear but may involve 
TABLE 1 | Comparative summary of previous work by others using the Walker 256 cell-CIBP model in rats.

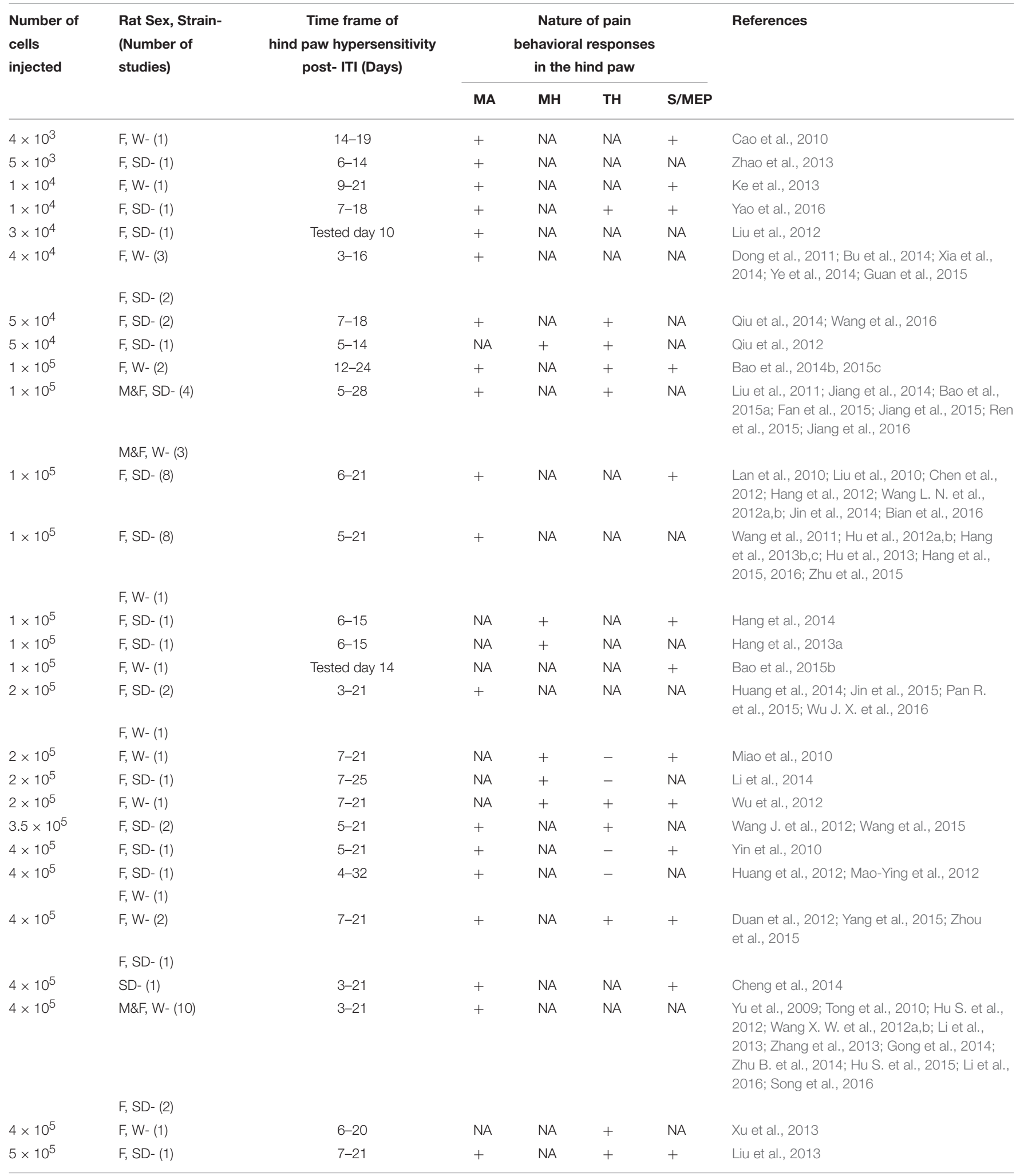


TABLE 1 | Continued

\begin{tabular}{|c|c|c|c|c|c|c|c|}
\hline \multirow[t]{2}{*}{$\begin{array}{l}\text { Number of } \\
\text { cells } \\
\text { injected }\end{array}$} & \multirow[t]{2}{*}{$\begin{array}{l}\text { Rat Sex, Strain- } \\
\text { (Number of } \\
\text { studies) }\end{array}$} & \multirow[t]{2}{*}{$\begin{array}{c}\text { Time frame of } \\
\text { hind paw hypersensitivity } \\
\text { post- ITI (Days) }\end{array}$} & \multicolumn{4}{|c|}{$\begin{array}{c}\text { Nature of pain } \\
\text { behavioral responses } \\
\text { in the hind paw }\end{array}$} & \multirow[t]{2}{*}{ References } \\
\hline & & & MA & MH & TH & S/MEP & \\
\hline \multirow[t]{2}{*}{$5 \times 10^{5}$} & F, SD- (5) & $5-21$ & + & NA & + & NA & $\begin{array}{l}\text { Bao et al., 2014a; Liu et al., 2014; Shen et al., } \\
\text { 2014; Hu X. M. et al., 2015; Zhang et al., 2015; } \\
\text { Zhu et al., } 2016\end{array}$ \\
\hline & $F, W-(1)$ & & & & & & \\
\hline $5 \times 10^{5}$ & $F, S D-(1)$ & $7-10$ & + & NA & NA & + & Lu et al., 2015 \\
\hline $5 \times 10^{5}$ & F, SD- (3) & $9-21$ & + & NA & NA & NA & Chen et al., 2013, 2015; Song et al., 2015 \\
\hline $5 \times 10^{5}$ & $\mathrm{~F}, \mathrm{SD}-(1)$ & $7-10$ & NA & + & NA & + & Lu et al., 2016 \\
\hline $5 \times 10^{5}$ & M, SD- (1) & $5-14$ & $\mathrm{NA}$ & + & NA & NA & Xu et al., 2015 \\
\hline $1 \times 10^{8}$ & F, SD- (1) & $7-25$ & + & NA & NA & NA & Zhao et al., 2010 \\
\hline
\end{tabular}

+, observed; -, not observed; F, female; M, male; MA, mechanical allodynia; MH, mechanical hyperalgesia; NA, not assessed; SD, Sprague Dawley; S/MEP, spontaneous or movementevoked pain; TH, thermal hyperalgesia; W, Wistar.

development of an adaptive immune response (Pardoll and Topalian, 1998; Rees and Mian, 1999), differential propagation of tumor sub clones in their microenvironment (Khong and Restifo, 2002) and consequent elimination by immune cells, antibodies, cytokines, and chemokines (Dunn et al., 2002, 2006; Bui and Schreiber, 2007; Jaganjac et al., 2008). Physical activity of the animals, exercise (Hoffman et al., 1962; Deminice et al., 2016b), dietary factors (Bekesi and Winzler, 1970; Kwong et al., 1984; Luty et al., 2016), or hormonal levels (Khegai, 2013; Khegay and Ivanova, 2015) may influence the regression of these cells or inhibit the activities driven by these cells (CamposFerraz et al., 2016; Cruz et al., 2016; Deminice et al., 2016a; Fracaro et al., 2016; Toneto et al., 2016). In most studies, tumor regression is generally overlooked as the tumor-bearing rats are sacrificed before regression is evident (Guimarães et al., 2010). Thus, the verification of tibial tumor burden post-mortem is very important. However, the beginning of pain behavior resolution at 20-25 days post-surgery is typically not due to tumor regression, but may involve neuro-immune mechanisms (Zhao et al., 2010; Xu et al., 2013; Huang et al., 2014). In previous work by others using different cancer cell lines, up regulation of the endogenous opioid system is implicated in spontaneous pain behavior resolution (Muralidharan et al., 2013). Similarly, endogenous opioid system could also have a role in Walker 256 cell-CIBP model (Li et al., 2016). In addition, lipoxins and endogenous lipoxygenase-derived eicosanoids, which represent a unique class of lipid mediators, have a broad spectrum of antiinflammatory and antinociceptive activities. These are known to suppress the expression of spinal pro-inflammatory cytokines and might also contribute to spontaneous resolution of Walker 256 cell-CIBP in rats (Hu S. et al., 2012). Inflammation, which is an important component of cancer pain (Falk and Dickenson, 2014) mostly involves active endogenous processes targeted at protecting the host, and is generally self-limiting and selfresolving (Chiang et al., 2005; Serhan and Savill, 2005; Schwab and Serhan, 2006).

\section{TARGETS FOR NOVEL ANALGESIC DRUG DISCOVERY}

The pathobiology of Walker 256 cell-CIBP in rats is complex involving inflammatory, neuropathic and tumorigenic components (Cao et al., 2010). Following injection, these cells cause osteolysis and bone resorption (Kurth et al., 2000, 2001; Yu et al., 2009) and increase oxidative stress and impair the antioxidant system in the bone microenvironment (Badraoui et al., 2009). They cause enhanced synthesis of IL-1 $\beta$ and TNF- $\alpha$ at the mRNA or protein level along with nuclear factor kappa-light-chain-enhancer of activated B cells (NF- $\mathrm{B})$, which indicates that increased neuroimmune responses is one of the important factors responsible for pain in this model (Cao et al., 2010; Song et al., 2016). Injection of these cells in the bones sequentially activates the extracellular signalregulated protein kinase $(\mathrm{ERK}) /$ mitogen-activated protein kinase (MAPK) pathway in various cell types in the spinal cord of rats (Wang et al., 2011; Wang X. W. et al., 2012b; Bian et al., 2016). Sodium channels expressed by sensory nerve fibers including voltage gated sodium ion channels $\left(\mathrm{Na}_{\mathrm{v}}\right)$ 1.7, $\mathrm{Na}_{\mathrm{v}} 1.8$, and $\mathrm{Na}_{\mathrm{v}} 1.9$ (Miao et al., 2010; Qiu et al., 2012; Pan J. et al., 2015) as well as potassium ion channels, high-voltage-activated calcium channels, hyperpolarizationactivated cation channels, transient receptor potential cation channel subfamily V member 1 (TRPV1) (Duan et al., 2012; $\mathrm{Xu}$ et al., 2013; Xia et al., 2014), and acid-sensing ion channel 3 (Qiu et al., 2014) may also be important determinants of enhanced neuronal excitability in this breast CIBP model in rats.

Pain behavior and its relief in Walker 256 cell-CIBP in rats is mediated by the endogenous effectors of several targets interacting with their cognate receptors as summarized in Table 2. These include important targets like opioid receptors, toll like receptors, chemokine receptors, and purinergic receptors. 
TABLE 2 | Role of endogenous effectors interacting with their cognate targets that mediate pain and analgesia in the Walker 256 cell- CIBP model in rats.

\begin{tabular}{|c|c|c|c|c|}
\hline Receptor & Ligand & $\begin{array}{l}\text { Downstream } \\
\text { molecule/effector }\end{array}$ & $\begin{array}{l}\text { In vivo pharmacological } \\
\text { modulator used }\end{array}$ & References \\
\hline Toll like receptor 4 (TLR4) & $\begin{array}{l}\text { Lipopolysaccharide (Saitoh } \\
\text { et al., 2004) }\end{array}$ & $\begin{array}{l}\text { TNF- } \alpha, \text { IL-1 } \beta ; \text { IL-6; } \\
\text { p38MAPK }\end{array}$ & $\begin{array}{l}\text { Inducible } \\
\text { Lentivirus-Mediated small } \\
\text { interfering RNA (siRNA) } \\
\text { against TLR4; p38MAPK } \\
\text { inhibitor- SB203580; TLR4 } \\
\text { blocker- lipopolysaccharide } \\
\text { Rhodobacter sphaeroides } \\
\text { (LPSRS) }\end{array}$ & $\begin{array}{l}\text { Lan et al., 2010; Liu et al., } \\
\text { 2010; Mao-Ying et al., } \\
\text { 2012; Li et al., 2013; Liu } \\
\text { et al., 2013; Pan R. et al., } \\
2015\end{array}$ \\
\hline $\begin{array}{l}\text { Lysophosphatidic acid } 1 \\
\text { (LPA1) receptor }\end{array}$ & Lysophosphatidic acid & $\begin{array}{l}\text { Phospholipase C, MAPK, } \\
\text { protein kinase B (Akt) (Yung } \\
\text { et al., 2014), Ras homolog } \\
\text { gene family (Rho), Rho- } \\
\text { associated protein kinase } \\
\text { (ROCK) }\end{array}$ & $\begin{array}{l}\text { LPA1 receptor blocker- } \\
\text { VPC32183; Rho inhibitor- } \\
\text { BoTXC3; ROCK inhibitor- } \\
\text { Y27632 }\end{array}$ & $\begin{array}{l}\text { Zhao et al., 2010; Wu J. X. } \\
\text { et al., } 2016\end{array}$ \\
\hline $\begin{array}{l}\text { Epidermal growth factor-like } \\
\text { receptor ErbB2 }\end{array}$ & Neuregulin 1 (NRG1) & Akt-1, p38MAPK & ErbB2 inhibitor & Jiang et al., 2014 \\
\hline $\begin{array}{l}\text { CX3C chemokine receptor } 1 \\
\text { (CX3CR1) }\end{array}$ & Fractalkine & p38MAPK & Anti-CX3CR1 antibody & $\begin{array}{l}\text { Yin et al., 2010; Hu et al., } \\
\text { 2012a; Cheng et al., } 2014\end{array}$ \\
\hline $\begin{array}{l}\text { CC chemokine receptor-2 } \\
\text { (CCR2) }\end{array}$ & $\begin{array}{l}\text { Chemokine monocyte } \\
\text { chemoattractant protein-1 } \\
\text { (MCP-1) }\end{array}$ & $\begin{array}{l}\text { phosphatidylinositol } \\
\text { 3-kinase (PI3K), Akt }\end{array}$ & $\begin{array}{l}\text { Anti-MCP-1 antibody; PI3K } \\
\text { inhibitor LY294002; } \\
\text { exogenous recombinant } \\
\text { MCP-1; CCR2 antagonist } \\
\text { RS102895 }\end{array}$ & $\begin{array}{l}\text { Hu et al., 2012b, 2013; Jin } \\
\text { et al., 2015; Ren et al., } 2015\end{array}$ \\
\hline $\begin{array}{l}\text { Chemokine (C-X-C motif) } \\
\text { receptor CXCR3 }\end{array}$ & CXCL9, CXCL10, CXCL11 & $\begin{array}{l}\text { Phosphoinositide }-3 \text { kinase } \\
\text { (PI3K), MAPK, Akt, ERK } 1 / 2 \\
\text { (Smit et al., 2003) }\end{array}$ & $\begin{array}{l}\text { Recombinant CXCL10 } \\
\text { protein, anti-CXCL10 } \\
\text { antibody, CXCR3 antagonist }\end{array}$ & $\begin{array}{l}\text { Bu et al., 2014; Guan et al., } \\
2015\end{array}$ \\
\hline $\begin{array}{l}\text { Purinergic } \mathrm{P} 2 \mathrm{X} 3 \text { receptor } \\
\text { (P2X3R) }\end{array}$ & Extracellular ATP & ERK (Seino et al., 2006) & $\begin{array}{l}\text { P2X3 receptor antagonist- } \\
\text { A-317491 }\end{array}$ & $\begin{array}{l}\text { Wu et al., 2012; Zhou et al., } \\
2015\end{array}$ \\
\hline $\begin{array}{l}\text { Purinergic P2X4 receptor } \\
\text { (P2X4R) }\end{array}$ & $\begin{array}{l}\text { Extracellular ATP (North, } \\
\text { 2002) }\end{array}$ & p38MAPK & P2X4R siRNA & Jin et al., 2014 \\
\hline $\begin{array}{l}\text { Purinergic P2X7 receptor } \\
\text { (P2X7R) }\end{array}$ & ATP & $\begin{array}{l}\text { IL-1 } \beta, \text { IL-18, } \\
\text { phosphorylated p38 } \\
\text { (Arulkumaran et al., 2011) }\end{array}$ & $\begin{array}{l}\text { inhibitor of P2X7R- Brilliant } \\
\text { Blue G (BBG); RNA } \\
\text { interference targeting the } \\
\text { P2X7R }\end{array}$ & $\begin{array}{l}\text { Huang et al., 2014; Yang } \\
\text { et al., } 2015\end{array}$ \\
\hline a3 glycine receptors & Glycine & $\begin{array}{l}\text { Chloride current modulation } \\
\text { (Avila et al., 2013) }\end{array}$ & $\begin{array}{l}\text { siRNA targeting a3 GlyR, } \\
\text { glycine receptor antagonist- } \\
\text { strychnine }\end{array}$ & Zhang et al., 2013 \\
\hline Adenosine $\mathrm{A} 1$ receptor & Adenosine & $\begin{array}{l}\text { Protein kinase C (PKC) } \\
\text { (Hughes et al., 2015) }\end{array}$ & $\begin{array}{l}\text { Adenosine A1 receptor } \\
\text { antagonist- DPCPX }\end{array}$ & Chen et al., 2013 \\
\hline $\begin{array}{l}\text { Protease-activated receptor } \\
2 \text { (PAR2) }\end{array}$ & $\begin{array}{l}\text { Trypsin and trypsin-like } \\
\text { proteinases }\end{array}$ & $N F-\kappa B$ & $\begin{array}{l}\text { PAR2 antagonist- } \\
\text { FSLLRY-NH2 }\end{array}$ & Bao et al., 2014a, 2015b \\
\hline
\end{tabular}


TABLE 2 | Continued

\begin{tabular}{|c|c|c|c|c|}
\hline Receptor & Ligand & $\begin{array}{l}\text { Downstream } \\
\text { molecule/effector }\end{array}$ & $\begin{array}{l}\text { In vivo pharmacological } \\
\text { modulator used }\end{array}$ & References \\
\hline $\begin{array}{l}\text { Protease-activated receptor } \\
4 \text { (PAR4) }\end{array}$ & Thrombin & $\begin{array}{l}\text { Vascular endothelial growth } \\
\text { factor (VEGF), endostatin } \\
\text { (Ma et al., 2005) }\end{array}$ & None & Bao et al., 2015c \\
\hline $\begin{array}{l}\text { Glucagon like peptide-1 } \\
\text { receptor (GLP-1R) }\end{array}$ & $\begin{array}{l}\text { Glucagon like peptide-1 } \\
\text { (GLP-1) }\end{array}$ & $\begin{array}{l}\text { Cyclic adenosine } \\
\text { monophosphate (cAMP), } \\
\text { protein kinase A (PKA) }\end{array}$ & $\begin{array}{l}\text { GLP-1R agonists } \\
\text { GLP-1(7-36) }\end{array}$ & Gong et al., 2014 \\
\hline $\begin{array}{l}\text { Cannabinoid receptor type } \\
2 \text { (CB2) }\end{array}$ & $\begin{array}{l}\text { 2-arachidonoylglycerol } \\
\text { (Basu et al., 2011) }\end{array}$ & IL-1 $\beta$, IL-6, IL-18, TNF- $\alpha$ & $\begin{array}{l}\text { CB2-selective antagonist- } \\
\text { AM630; CB2-selective } \\
\text { agonist- JWH-015 }\end{array}$ & Lu et al., 2015, 2016 \\
\hline $\begin{array}{l}\text { Prokineticin receptor } 2 \\
\text { (PKR2) }\end{array}$ & Bv8 (prokineticin 2) & TNF- $\alpha$ & Bv8 neutralizing antibody & Hang et al., 2015 \\
\hline $\begin{array}{l}\text { Corticotropin-releasing } \\
\text { factor (CRF) receptor }\end{array}$ & $\begin{array}{l}\text { Corticotropin-releasing } \\
\text { factor (CRF) }\end{array}$ & $\begin{array}{l}\text { PKA, NF-кB, ERK 1/2 } \\
\text { (Taché and Million, 2015) }\end{array}$ & $\begin{array}{l}\text { CRF receptor antagonist } \\
(\alpha \text {-helical-CRF) }\end{array}$ & Fan et al., 2015 \\
\hline$\mu$-opioid receptor (MOR) & Endomorphin-2 & $\begin{array}{l}\text { Guanosine triphosphate } \\
\text { (GTP), adenosine } \\
\text { diphosphate (ADP) } \\
\text { (Al-Hasani and Bruchas, } \\
\text { 2011) }\end{array}$ & $\begin{array}{l}\text { MOR antagonist- } \\
\beta \text {-funaltrexamine }(\beta-F N A)\end{array}$ & $\begin{array}{l}\text { Chen et al., 2015; Jiang } \\
\text { et al., 2016; Yao et al., } 2016\end{array}$ \\
\hline Sigma-1 Receptor & $\begin{array}{l}\text { Tryptaminergic trace } \\
\text { amines, as well as } \\
\text { neuroactive steroids such } \\
\text { as dehydroepiandrosterone } \\
\text { (DHEA) and pregnenolone } \\
\text { (Fontanilla et al., 2009) }\end{array}$ & Inositol trisphosphate (IP3) & $\begin{array}{l}\text { Sigma-1 receptor } \\
\text { antagonist -BD1047 }\end{array}$ & Zhu et al., 2015 \\
\hline $\begin{array}{l}\text { N-Methyl-D-Aspartate } \\
\text { (NMDA) Receptor }\end{array}$ & $\begin{array}{l}\text { Glutamate, glycine or } \\
\text { D-serine (Hogan-Cann and } \\
\text { Anderson, 2016) }\end{array}$ & $\begin{array}{l}\text { PKA, MAPK (Zhao et al., } \\
\text { 2016) }\end{array}$ & None & Wang L. N. et al., 2012a \\
\hline
\end{tabular}

\section{LIMITATIONS AND POTENTIAL IMPROVEMENT OF THE MODEL}

Like many other preclinical models, this model has shortcomings which might hinder translation of promising preclinical data into successful clinical outcomes. Mostly, efficacy profiling in preclinical pain models is driven by a desire to reduce the intensity of pain behavioral readouts. However, a reduction in pain intensity is not always a good measure of the success of a pain treatment (Ballantyne and Sullivan, 2015). Pain is a subjective emotional experience and clinically, a powerful analgesic response can be elicited by placebo treatment (Kaptchuk and Miller, 2015; Tuttle et al., 2015). Hence, responses in experimental animals may not necessarily correlate with the responses expected from humans in the clinical setting. It is also necessary to remember that animals at different ages may process nociception differently (McKelvey et al., 2015) and hence, selection of the correct age of animals that suits the experimental goals may be critical.

Important factors that significantly affect pain research outcomes, such as the sex of the researchers interacting with the animals (Sorge et al., 2014) should not be overlooked in preclinical studies. Sex of the experimental animals or human subjects is a key source of variation in pro-nociceptive signaling (Wiesenfeld-Hallin, 2005; Sorge et al., 2015). In a recent largescale gene regulatory study (Qu et al., 2015), the main findings were that men and women may require different strategies for treatment of pain, and so sex differences in pain research should not be ignored (Murphy et al., 2009; Vacca et al., 2014, 2016; Brings and Zylka, 2015; Cahill and Aswad, 2015; Ferrarelli, 2015).

There are many types of breast cancer in the clinical setting (Sharma et al., 2010) with the potential to cause pain, and the extent to which this model provides insights into these various subtypes is currently unclear. It is also important to have standardized protocols when using such preclinical models in order to minimize between-investigator and between-laboratory differences in implementation (Freedman and Gibson, 2015).

\section{CONCLUSION}

Cancer-associated pain, especially intractable bone pain, is very debilitating (Kane et al., 2015). Although, this model involving ITI of Walker 256 cells in rats might not exactly mimic the metastatic spread of breast cancer to the axial skeleton in humans (Kurth et al., 2001, 2002), it provides great insights into the pathobiology and mechanisms of breast CIBP and is hence used very widely in experimental research (Du et al., 2015; Hang et al., 2015; Hu S. et al., 2015; Liu et al., 2015; Lu et al., 2015). Undoubtedly, it is one of the most suitable preclinical models for efficacy assessment of novel compounds from discovery 
programs aimed at identifying drugs with potential to alleviate breast CIBP in humans.

\section{AUTHOR CONTRIBUTIONS}

All authors (PS, AK, IV, and MS) meet the essential authorship criteria required by the journal including (a) substantial contributions to the conception and design of this article; the acquisition, analysis, and interpretation of the work, (b) drafting the work and revising it critically for important intellectual content, (c) final approval of the version to be published, and (d) agreement to be accountable for all aspects of the work

\section{REFERENCES}

Al-Hasani, R., and Bruchas, M. R. (2011). Molecular mechanisms of opioid receptor-dependent signaling and behavior. Anesthesiology 115, 1363-1381. doi: 10.1097/aln.0b013e318238bba6

Arulkumaran, N., Unwin, R. J., and Tam, F. W. K. (2011). A potential therapeutic role for $\mathrm{P} 2 \mathrm{X} 7$ receptor (P2X7R) antagonists in the treatment of inflammatory diseases. Expert Opin. Investig. Drugs 20, 897-915. doi: $10.1517 / 13543784.2011 .578068$

Avila, A., Nguyen, L., and Rigo, J. M. (2013). Glycine receptors and brain development. Front. Cell. Neurosci 7:184. doi: 10.3389/fncel.2013.00184

Badraoui, R., Blouin, S., Moreau, M. F., Gallois, Y., Rebai, T., Sahnoun, Z., et al. (2009). Effect of alpha tocopherol acetate in Walker 256/B cells-induced oxidative damage in a rat model of breast cancer skeletal metastases. Chem. Biol. Interact. 182, 98-105. doi: 10.1016/j.cbi.2009.09.010

Ballantyne, J. C., and Sullivan, M. D. (2015). Intensity of chronic pain-the wrong metric? N. Engl. J. Med. 373, 2098-2099. doi: 10.1056/NEJMp1507136

Bao, Y., Gao, Y., Hou, W., Yang, L., Kong, X., Zheng, H., et al. (2015a). Engagement of signaling pathways of protease-activated receptor 2 and mu-opioid receptor in bone cancer pain and morphine tolerance. Int. J. Cancer 137, 1475-1483. doi: $10.1002 / \mathrm{ijc} .29497$

Bao, Y., Hou, W., Liu, R., Gao, Y., Kong, X., Yang, L., et al. (2014a). PAR2-mediated upregulation of BDNF contributes to central sensitization in bone cancer pain. Mol. Pain 10:28. doi: 10.1186/1744-8069-10-28

Bao, Y., Hou, W., Yang, L., Kong, X., Du, M., Zheng, H., et al. (2015b). Proteaseactivated receptor 2 antagonist potentiates analgesic effects of systemic morphine in a rat model of bone cancer pain. Reg. Anesth. Pain Med. 40, 158-165. doi: 10.1097/aap.0000000000000211

Bao, Y., Hou, W., Yang, L., Liu, R., Gao, Y., Kong, X., et al. (2015c). Increased expression of protease-activated receptor 2 and 4 within dorsal root ganglia in a rat model of bone cancer pain. J. Mol. Neurosci. 55, 706-714. doi: 10.1007/s12031-014-0409-1

Bao, Y., Hua, B., Hou, W., Shi, Z., Li, W., Li, C., et al. (2014b). Involvement of protease-activated receptor 2 in nociceptive behavior in a rat model of bone cancer. J. Mol. Neurosci. 52, 566-576. doi: 10.1007/s12031-013-0112-7

Barry, I. (2009). The regression question. Nat. Rev. Cancer 9, 8-8. doi: $10.1038 / \mathrm{nrc} 2575$

Basu, S., Ray, A., and Dittel, B. N. (2011). Cannabinoid receptor 2 is critical for the homing and retention of marginal zone B lineage cells and for efficient T-independent immune responses. J. Immunol. 187, 5720-5732. doi: 10.4049/jimmunol.1102195

Bekesi, J. G., and Winzler, R. J. (1970). Inhibitory effects of d-glucosamine on the growth of walker 256 Carcinosarcoma and on protein, RNA, and DNA synthesis. Cancer Res. 30, 2905-2912.

Bian, J., Zhu, S., Ma, W., Li, C., and Ashraf, M. A. (2016). Analgesic effect and possible mechanism of SCH772984 intrathecal injection on rats with bone cancer pain. Saudi Pharm. J. 24, 354-362. doi: 10.1016/j.jsps.2016.04.017

Blouin, S., Baslé, M. F., and Chappard, D. (2005). Rat models of bone metastases. Clin. Exp. Metastasis 22, 605-614. doi: 10.1007/s10585-006-9002-5

Brigatte, P., Faiad, O. J., Ferreira Nocelli, R. C., Landgraf, R. G., Palma, M. S., Cury, Y., et al. (2016). Walker 256 tumor growth suppression by crotoxin involves in ensuring that questions related to the accuracy or integrity of any part of the work are appropriately investigated and resolved.

\section{ACKNOWLEDGMENTS}

PS is supported by The University of Queensland's International PhD Scholarship. AK is supported by Post-Doctoral Fellowship funded by an Australian Research Council Large Linkage Grant (LP120200623) in collaboration with industry (Boehringer Ingelheim Pharma Gmbh \& Co. KG). IV is supported by an Australian Research Council Future Fellowship.

formyl peptide receptors and lipoxin A4. Mediators Inflamm. 2016:2457532. doi: $10.1155 / 2016 / 2457532$

Brigatte, P., Sampaio, S. C., Gutierrez, V. P., Guerra, J. L., Sinhorini, I. L., Curi, R., et al. (2007). Walker 256 tumor-bearing rats as a model to study cancer pain. J. Pain 8, 412-421. doi: 10.1016/j.jpain.2006.11.006

Brings, V. E., and Zylka, M. J. (2015). Sex, drugs and pain control. Nat. Neurosci. 18, 1059-1060. doi: 10.1038/nn.4057

Bu, H., Shu, B., Gao, F., Liu, C., Guan, X., Ke, C., et al. (2014). Spinal IFN-gammainduced protein-10 (CXCL10) mediates metastatic breast cancer-induced bone pain by activation of microglia in rat models. Breast Cancer Res. Treat. 143, 255-263. doi: 10.1007/s10549-013-2807-4

Buehring, G. C., Eby, E. A., and Eby, M. J. (2004). Cell line cross-contamination: how aware are Mammalian cell culturists of the problem and how to monitor it? In Vitro Cell. Dev. Biol. Anim. 40, 211-215. doi: 10.1290/1543$706 x(2004) 40<211$ :clchaa $>2.0 . c 0 ; 2$

Bui, J. D., and Schreiber, R. D. (2007). Cancer immunosurveillance, immunoediting and inflammation: independent or interdependent processes? Curr. Opin. Immunol. 19, 203-208. doi: 10.1016/j.coi.2007.02.001

Burnside, E. S., Trentham-Dietz, A., Kelcz, F., and Collins, J. (2006). An example of breast cancer regression on imaging. Radiol. Case Rep. 1, 27-37. doi: 10.2484/rcr.vli2.4

Cahill, L., and Aswad, D. (2015). Sex influences on the brain: an issue whose time has come. Neuron 88, 1084-1085. doi: 10.1016/j.neuron.2015.11.021

Campos-Ferraz, P. L., Gualano, B., das Neves, W., Andrade, I. T., Hangai, I., Pereira, R. T., et al. (2016). Exploratory studies of the potential anti-cancer effects of creatine. Amino Acids 48, 1993-2001. doi: 10.1007/s00726-016-2180-9

Cao, F., Gao, F., Xu, A. J., Chen, Z. J., Chen, S. S., Yang, H., et al. (2010). Regulation of spinal neuroimmune responses by prolonged morphine treatment in a rat model of cancer induced bone pain. Brain Res. 1326, 162-173. doi: 10.1016/j.brainres.2010.02.039

Cavalcanti, T. C., Gregorini, C. C., Guimarães, F., Rettori, O., and Vieira-Matos, A. N. (2003). Changes in red blood cell osmotic fragility induced by total plasma and plasma fractions obtained from rats bearing progressive and regressive variants of the Walker 256 tumor. Braz. J. Med. Biol. Res. 36, 887-895. doi: 10.1590/S0100-879X2003000700009

Chacur, M., Milligan, E. D., Gazda, L. S., Armstrong, C., Wang, H., Tracey, K. J., et al. (2001). A new model of sciatic inflammatory neuritis (SIN): induction of unilateral and bilateral mechanical allodynia following acute unilateral peri-sciatic immune activation in rats. Pain 94, 231-244. doi: 10.1016/S03043959(01)00354-2

Chang-Liu, C. M., and Woloschak, G. E. (1997). Effect of passage number on cellular response to DNA-damaging agents: cell survival and gene expression. Cancer Lett. 113, 77-86. doi: 10.1016/S0304-3835(97)04599-0

Chen, J., Wang, L., Zhang, Y., and Yang, J. (2012). P2Y1 purinoceptor inhibition reduces extracellular signal-regulated protein kinase $1 / 2$ phosphorylation in spinal cord and dorsal root ganglia: implications for cancer-induced bone pain. Acta Biochim. Biophys. Sin. (Shanghai). 44, 367-372. doi: 10.1093/abbs/gms007

Chen, L., Wang, K., Yang, T., Wang, W., Mei, X. P., Zhu, C., et al. (2015). Downregulation of spinal endomorphin-2 correlates with mechanical allodynia in a rat model of tibia cancer. Neuroscience 286, 151-161. doi: 10.1016/j.neuroscience.2014.11.049 
Chen, L., Zhu, L., Wang, K., Wang, W., Mei, X. P., Liu, T., et al. (2013). Antinociceptive effect of prostatic acid phosphatase in a rat model of cancerinduced bone pain. Pain Physician 16, 533-546.

Cheng, W., Zhao, Y., Liu, H., Fan, Q., Lu, F. F., Li, J., et al. (2014). Resveratrol attenuates bone cancer pain through the inhibition of spinal glial activation and CX3CR1 upregulation. Fundam. Clin. Pharmacol. 28, 661-670. doi: $10.1111 /$ fcp. 12084

Chiang, N., Arita, M., and Serhan, C. N. (2005). Anti-inflammatory circuitry: lipoxin, aspirin-triggered lipoxins and their receptor ALX. Prostaglandins Leukot. Essent. Fatty Acids 73, 163-177. doi: 10.1016/j.plefa.2005.05.003

Coleman, R. E. (2006). Clinical features of metastatic bone disease and risk of skeletal morbidity. Clin. Cancer Res. $12(20$ Pt 2), 6243s-6249s. doi: 10.1158/1078-0432.CCR-06-0931

Colvin, L., and Fallon, M. (2008). Challenges in cancer pain management-bone pain. Eur. J. Cancer 44, 1083-1090. doi: 10.1016/j.ejca.2008.03.001

Cruz, B. L., da Silva, P. C., Tomasin, R., Oliveira, A. G., Viana, L. R., Salomao, E. M., et al. (2016). Dietary leucine supplementation minimises tumour-induced damage in placental tissues of pregnant, tumour-bearing rats. BMC Cancer 16:58. doi: 10.1186/s12885-016-2103-x

Currie, G. L., Delaney, A., Bennett, M. I., Dickenson, A. H., Egan, K. J., Vesterinen, H. M., et al. (2013). Animal models of bone cancer pain: systematic review and meta-analyses. Pain 154, 917-926. doi: 10.1016/j.pain.2013.02.033

Deminice, R., Cella, P. S., Padilha, C. S., Borges, F. H., da Silva, L. E., Campos-Ferraz, P. L., et al. (2016a). Creatine supplementation prevents hyperhomocysteinemia, oxidative stress and cancer-induced cachexia progression in Walker-256 tumor-bearing rats. Amino Acids 48, 2015-2024. doi: 10.1007/s00726-016-2172-9

Deminice, R., Padilha, C. S., Borges, F., da Silva, L. E., Rosa, F. T., Robinson, J. L., et al. (2016b). Resistance exercise prevents impaired homocysteine metabolism and hepatic redox capacity in Walker-256 tumor-bearing male Wistar rats. Nutrition 32, 1153-1158. doi: 10.1016/j.nut.2016.03.008

Dong, Y., Mao-Ying, Q. L., Chen, J. W., Yang, C. J., Wang, Y. Q., and Tan, Z. M. (2011). Involvement of EphB1 receptor/ephrinB1 ligand in bone cancer pain. Neurosci. Lett. 496, 163-167. doi: 10.1016/j.neulet.2011.04.008

Du, J., Fang, J., Chen, Y., Wu, S., Liang, Y., and Fang, J. (2015). [Parametric optimization of electroacupuncture against bone-cancer pain in rats and its intervention on mRNA expression of opioid receptor and precursor]. Zhongguo Zhen Jiu 35, 161-168.

Duan, K. Z., Xu, Q., Zhang, X. M., Zhao, Z. Q., Mei, Y. A., and Zhang, Y. Q. (2012). Targeting A-type $\mathrm{K}(+)$ channels in primary sensory neurons for bone cancer pain in a rat model. Pain 153, 562-574. doi: 10.1016/j.pain.2011.11.020

Dunn, G. P., Bruce, A. T., Ikeda, H., Old, L. J., and Schreiber, R. D. (2002). Cancer immunoediting: from immunosurveillance to tumor escape. Nat. Immunol. 3, 991-998. doi: 10.1038/ni1102-991

Dunn, G. P., Koebel, C. M., and Schreiber, R. D. (2006). Interferons, immunity and cancer immunoediting. Nat. Rev. Immunol. 6, 836-848. doi: 10.1038/nril961

Earle, W. R. (1935). A study of the walker rat mammary carcinoma 256, in vivo and in vitro. Am. J. Cancer 24, 566-612.

Falk, S., and Dickenson, A. H. (2014). Pain and nociception: mechanisms of cancer-induced bone pain. J. Clin. Oncol. 32, 1647-1654. doi: 10.1200/JCO.2013.51.7219

Fallon, M., Hoskin, P. J., Colvin, L. A., Fleetwood-Walker, S. M., Adamson, D., Byrne, A., et al. (2016). Randomized double-blind trial of pregabalin versus placebo in conjunction with palliative radiotherapy for cancer-induced bone pain. J. Clin. Oncol. 34, 550-556. doi: 10.1200/JCO.2015.63.8221

Fan, H., Xiao-Ling, S., Yaliu, S., Ming-Ming, L., Xue, F., Xian-Sheng, M., et al. (2016). Comparative pharmacokinetics of ginsenoside $\mathrm{Rg} 3$ and ginsenoside Rh2 after oral administration of ginsenoside $\mathrm{Rg} 3$ in normal and walker 256 tumor-bearing rats. Pharmacogn. Mag. 12, 21-24. doi: 10.4103/09731296.176014

Fan, H. B., Zhang, T., Sun, K., Song, S.-P., Cao, S.-B., Zhang, H.-L., et al. (2015). Corticotropin-releasing factor mediates bone cancer induced pain through neuronal activation in rat spinal cord. Tumor Biol. 36, 9559-9565. doi: 10.1007/s13277-015-3670-1

Fernandes, C., Monteiro, S., Belchior, A., Marques, F., Gano, L., Correia, J. D., et al. (2016). Novel (188)Re multi-functional bone-seeking compounds: synthesis, biological and radiotoxic effects in metastatic breast cancer cells. Nucl. Med. Biol. 43, 150-157. doi: 10.1016/j.nucmedbio.2015.11.004
Ferrarelli, L. (2015). Why women feel more pain. Sci. Signal. 8, ec212. doi: 10.1126/scisignal.aad1342

Fidler, I. J. (1978). Tumor heterogeneity and the biology of cancer invasion and metastasis. Cancer Res. 38, 2651-2660.

Fontanilla, D., Johannessen, M., Hajipour, A. R., Cozzi, N. V., Jackson, M. B., and Ruoho, A. E. (2009). The hallucinogen N,N-dimethyltryptamine (DMT) is an endogenous sigma-1 receptor regulator. Science 323, 934-937. doi: $10.1126 /$ science. 1166127

Fracaro, L., Frez, F. C., Silva, B. C., Vicentini, G. E., de Souza, S. R., Martins, H. A., et al. (2016). Walker 256 tumor-bearing rats demonstrate altered interstitial cells of Cajal. Effects on ICC in the Walker 256 tumor model. Neurogastroenterol. Motil. 28, 101-115. doi: 10.1111/nmo.12702

Freedman, L. P., and Gibson, M. C. (2015). The impact of preclinical irreproducibility on drug development. Clin. Pharmacol. Ther. 97, 16-18. doi: $10.1002 /$ cpt.9

Galuppo, L. F., Dos Reis Lívero, F. A., Martins, G. G., Cardoso, C. C., Beltrame, O. C., Klassen, L. M., et al. (2016). Sydnone 1: a mesoionic compound with antitumoral and haematological effects in vivo. Basic Clin. Pharmacol. Toxicol. 119, 41-50. doi: 10.1111/bcpt.12545

Gambeta, E., Kopruszinski, C. M., Dos Reis, R. C., Zanoveli, J. M., and Chichorro, J. G. (2016). Evaluation of heat hyperalgesia and anxiety likebehaviors in a rat model of orofacial cancer. Neurosci. Lett. 619, 100-105. doi: 10.1016/j.neulet.2016.03.001

Gao, H., Zhu, J., Li, Y., Fu, P., and Shen, B. (2016). Inhibitory effect of endostatin gene therapy combined with phosphorus-32 colloid on tumor growth in Wistar rats. Biosci. Rep. 36:e00353. doi: 10.1042/BSR20160117

Gong, N., Xiao, Q., Zhu, B., Zhang, C. Y., Wang, Y. C., Fan, H., et al. (2014). Activation of spinal glucagon-like peptide-1 receptors specifically suppresses pain hypersensitivity. J. Neurosci. 34, 5322-5334. doi: 10.1523/JNEUROSCI.4703-13.2014

Guan, X. H., Fu, Q. C., Shi, D., Bu, H. L., Song, Z. P., Xiong, B. R., et al. (2015). Activation of spinal chemokine receptor CXCR3 mediates bone cancer pain through an Akt-ERK crosstalk pathway in rats. Exp. Neurol. 263, 39-49. doi: 10.1016/j.expneurol.2014.09.019

Gui, Q., Xu, C., Li, D., Zhuang, L., Xia, S., and Yu, S. (2015). Urinary N telopeptide levels in predicting the anti-nociceptive responses of zoledronic acid and paclitaxel in a rat model of bone metastases. Mol. Med. Rep. 12, 4243-4249. doi: 10.3892/mmr.2015.3948

Gui, Q., Xu, C., Zhuang, L., Xia, S., Chen, Y., Peng, P., et al. (2013). A new rat model of bone cancer pain produced by rat breast cancer cells implantation of the shaft of femur at the third trochanter level. Cancer Biol. Ther. 14, 193-199. doi: 10.4161/cbt.23291

Guimarães, F., Schanoski, A. S., Cavalcanti, T. C. S., Juliano, P. B., Viera-Matos, A. N., and Rettori, O. (2010). Tumor growth characteristics of the Walker 256 AR tumor, a regressive variant of the rat Walker 256 A tumor. Braz. Arch. Biol. Technol. 53, 1101-1108. doi: 10.1590/S1516-89132010000500014

Hahn, T., Szabo, L., Gold, M., Ramanathapuram, L., Hurley, L. H., and Akporiaye, E. T. (2006). Dietary administration of the proapoptotic vitamin E analogue alpha-tocopheryloxyacetic acid inhibits metastatic murine breast cancer. Cancer Res. 66, 9374-9378. doi: 10.1158/0008-5472.CAN-06-2403

Hang, L.-H., Li, S.-N., Luo, H., Shu, W.-W., Mao, Z.-M., Chen, Y.-F., et al. (2016). Connexin 43 mediates CXCL12 production from spinal dorsal horn to maintain bone cancer pain in rats. Neurochem. Res. 41, 1200-1208. doi: 10.1007/s11064-0151815-7

Hang, L. H., Li, S. N., Shao, D. H., Chen, Z., Chen, Y. F., and Shu, W. W. (2014). Evidence for involvement of spinal RANTES in the antinociceptive effects of triptolide, a diterpene triepoxide, in a rat model of bone cancer pain. Basic Clin. Pharmacol. Toxicol. 115, 477-480. doi: 10.1111/bcpt.12265

Hang, L. H., Luo, H., Li, S. N., Shu, W. W., Chen, Z., Chen, Y. F., et al. (2015). Involvement of spinal bv8/prokineticin 2 in a rat model of cancer-induced bone pain. Basic Clin. Pharmacol. Toxicol. 117, 180-185. doi: 10.1111/bcpt.12386

Hang, L.-H., Shao, D.-H., Chen, Z., Chen, Y.-F., Shu, W.-W., and Zhao, Z.-G. (2013a). Involvement of spinal CC chemokine ligand 5 in the development of bone cancer pain in rats. Basic Clin. Pharmacol. Toxicol. 113, 325-328. doi: 10.1111/bcpt.12099

Hang, L.-H., Shao, D. H., Chen, Z., and Sun, W. J. (2013b). Spinal RhoA/Rho kinase signalling pathway may participate in the development of bone 
cancer pain. Basic Clin. Pharmacol. Toxicol. 113, 87-91. doi: 10.1111/bcpt. 12069

Hang, L. H., Yang, J. P., Shao, D. H., Chen, Z., and Wang, H. (2013c). Involvement of spinal PKA/CREB signaling pathway in the development of bone cancer pain. Pharmacol. Rep. 65, 710-716. doi: 10.1016/S1734-1140(13)71049-1

Hang, L. H., Yang, J. P., Yin, W., Wang, L. N., Guo, F., Ji, F. H., et al. (2012). Activation of spinal TDAG8 and its downstream PKA signaling pathway contribute to bone cancer pain in rats. Eur. J. Neurosci. 36, 2107-2117. doi: 10.1111/j.1460-9568.2012.08087.x

Hoffman, S. A., Paschkis, K. E., Debias, D. A., Cantarow, A., and Williams, T. L. (1962). The influence of exercise on the growth of transplanted rat tumors. Cancer Res. 22, 597-599.

Hogan-Cann, A. D., and Anderson, C. M. (2016). Physiological roles of non-neuronal NMDA receptors. Trends Pharmacol. Sci. 37, 750-767. doi: 10.1016/j.tips.2016.05.012

Hu, J. H., Wu, M. Y., Tao, M., and Yang, J. P. (2013). Changes in protein expression and distribution of spinal CCR2 in a rat model of bone cancer pain. Brain Res. 1509, 1-7. doi: 10.1016/j.brainres.2013.03.002

Hu, J. H., Yang, J. P., Liu, L., Li, C. F., Wang, L. N., Ji, F. H., et al. (2012a). Involvement of CX3CR1 in bone cancer pain through the activation of microglia p38 MAPK pathway in the spinal cord. Brain Res. 1465, 1-9. doi: 10.1016/j.brainres.2012.05.020

Hu, J. H., Zheng, X. Y., Yang, J. P., Wang, L. N., and Ji, F. H. (2012b). Involvement of spinal monocyte chemoattractant protein-1 (MCP-1) in cancer-induced bone pain in rats. Neurosci. Lett. 517, 60-63. doi: 10.1016/j.neulet.2012.04.026

Hu, S., Chen, Y., Wang, Z. F., Mao-Ying, Q. L., Mi, W. L., Jiang, J. W., et al. (2015). The analgesic and antineuroinflammatory effect of baicalein in cancerinduced bone pain. Evid. Based Complement. Alternat. Med. 2015:973524. doi: $10.1155 / 2015 / 973524$

Hu, S., Mao-Ying, Q. L., Wang, J., Wang, Z. F., Mi, W. L., Wang, X. W., et al. (2012). Lipoxins and aspirin-triggered lipoxin alleviate bone cancer pain in association with suppressing expression of spinal proinflammatory cytokines. J. Neuroinflamm. 9:278. doi: 10.1186/1742-2094-9-278

Hu, X. M., Liu, Y. N., Zhang, H. L., Cao, S. B., Zhang, T., Chen, L. P., et al. (2015). CXCL12/CXCR4 chemokine signaling in spinal glia induces pain hypersensitivity through MAPKs-mediated neuroinflammation in bone cancer rats. J. Neurochem. 132, 452-463. doi: 10.1111/jnc.12985

Huang, J. L., Chen, X. L., Guo, C., and Wang, Y. X. (2012). Contributions of spinal D-amino acid oxidase to bone cancer pain. Amino Acids 43, 1905-1918. doi: 10.1007/s00726-012-1390-Z

Huang, Z. X., Lu, Z. J., Ma, W. Q., Wu, F. X., Zhang, Y. Q., Yu, W. F., et al. (2014). Involvement of RVM-expressed $\mathrm{P} 2 \mathrm{X} 7$ receptor in bone cancer pain: mechanism of descending facilitation. Pain 155, 783-791. doi: 10.1016/j.pain.2014.01.011

Hughes, S. J., Cravetchi, X., Vilas, G., and Hammond, J. R. (2015). Adenosine A1 receptor activation modulates human equilibrative nucleoside transporter 1 (hENT1) activity via PKC-mediated phosphorylation of serine-281. Cell. Signal. 27, 1008-1018. doi: 10.1016/j.cellsig.2015.02.023

Hutter, R. V. P. (1982). Assessment: is cured early cancer truly cancer? CA Cancer J. Clin. 32, 2-9.

Ibrahim, T., Mercatali, L., and Amadori, D. (2013). A new emergency in oncology: bone metastases in breast cancer patients (Review). Oncol. Lett. 6, 306-310. doi: 10.3892/ol.2013.1372

Jaganjac, M., Poljak-Blazi, M., Zarkovic, K., Schaur, R. J., and Zarkovic, N. (2008). The involvement of granulocytes in spontaneous regression of Walker 256 carcinoma. Cancer Lett. 260, 180-186. doi: 10.1016/j.canlet.2007.10.039

Jensen, G., and Müntzing, J. (1970). Differences in the growth of the Walker carcinoma in Sprague-Dawley and Wistar rats. Z. Krebsforsch. 74, 55-58. doi: 10.1007/BF00524680

Jiang, J., Zhang, J., Yao, P., Wu, X., and Li, K. (2014). Activation of spinal neuregulin 1-ErbB2 signaling pathway in a rat model of cancer-induced bone pain. Int. J. Oncol. 45, 235-244. doi: 10.3892/ijo.2014.2429

Jiang, Z., Wu, S., Wu, X., Zhong, J., Lv, A., Jiao, J., et al. (2015). Blocking mammalian target of rapamycin alleviates bone cancer pain and morphine tolerance via $\mu$-opioid receptor. Int. J. Cancer. 138, 2013-2020. doi: 10.1002/ijc. 29927

Jiang, Z., Wu, S., Wu, X., Zhong, J., Lv, A., Jiao, J., et al. (2016). Blocking mammalian target of rapamycin alleviates bone cancer pain and morphine tolerance via micro-opioid receptor. Int. J. Cancer 138, 2013-2020. doi: $10.1002 / \mathrm{ijc} .29927$

Jin, D., Yang, J. P., Hu, J. H., Wang, L. N., and Zuo, J. L. (2015). MCP-1 stimulates spinal microglia via PI3K/Akt pathway in bone cancer pain. Brain Res. 1599, 158-167. doi: 10.1016/j.brainres.2014.12.043

Jin, X. H., Wang, L. N., Zuo, J. L., Yang, J. P., and Liu, S. L. (2014). P2X4 receptor in the dorsal horn partially contributes to brain-derived neurotrophic factor oversecretion and toll-like receptor-4 receptor activation associated with bone cancer pain. J. Neurosci. Res. 92, 1690-1702. doi: 10.1002/jnr.23443

Justice, A. (1985). Review of the effects of stress on cancer in laboratory animals: importance of time of stress application and type of tumor. Psychol. Bull. 98, 108-138. doi: 10.1037/0033-2909.98.1.108

Kane, C. M., Hoskin, P., and Bennett, M. I. (2015). Cancer induced bone pain. BMJ 350:h315. doi: 10.1136/bmj.h315

Kaptchuk, T. J., and Miller, F. G. (2015). Placebo effects in medicine. N. Eng. J. Med. 373, 8-9. doi: 10.1056/NEJMp1504023

Ke, C., Li, C., Huang, X., Cao, F., Shi, D., He, W., et al. (2013). Protocadherin 20 promotes excitatory synaptogenesis in dorsal horn and contributes to bone cancer pain. Neuropharmacology 75, 181-190. doi: 10.1016/j.neuropharm.2013.07.010

Khegai, I. I. (2013). [Concordance between vasopressin gene expression and growth of Walker 256 carcinosarcoma in rats]. Genetika 49, 538-540. doi: $10.1134 /$ s1022795413030101

Khegay, I. I., and Ivanova, L. N. (2015). Regression of Walker 256 carcinosarcoma in vasopressin-deficient Brattleboro rats is accompanied by a changed laminin pattern. Biochem. Genet. 53, 1-7. doi: 10.1007/s10528-015-9665-1

Khong, H. T., and Restifo, N. P. (2002). Natural selection of tumor variants in the generation of "tumor escape" phenotypes. Nat. Immunol. 3, 999-1005. doi: 10.1038/ni1102-999

Koltzenburg, M., Wall, P. D., and McMahon, S. B. (1999). Does the right side know what the left is doing? Trends Neurosci. 22, 122-127.

Kurth, A. A., Kim, S. Z., Sedlmeyer, I., Bauss, F., and Shea, M. (2002). Ibandronate treatment decreases the effects of tumor-associated lesions on bone density and strength in the rat. Bone 30, 300-306. doi: 10.1016/S8756-3282(01)00644-5

Kurth, A. H., Kim, S. Z., Sedlmeyer, I., Hovy, L., and Bauss, F. (2000). Treatment with ibandronate preserves bone in experimental tumour-induced bone loss. J. Bone Joint Surg. Br. 82, 126-130. doi: 10.1302/0301-620X.82B1.9483

Kurth, A. H., Wang, C., Hayes, W. C., and Shea, M. (2001). The evaluation of a rat model for the analysis of densitometric and biomechanical properties of tumor-induced osteolysis. J. Orthop. Res. 19, 200-205. doi: 10.1016/S07360266(00)90014-7

Kwong, E., Nesheim, M. C., and Dills, W. L. Jr. (1984). The influence of diet on the regression of the Walker carcinosarcoma 256 in rats. J. Nutr. 114, 2324-2330.

Lan, L. S., Ping, Y. J., Na, W. L., Miao, J., Cheng, Q. Q., Ni, M. Z., et al. (2010). Down-regulation of Toll-like receptor 4 gene expression by short interfering RNA attenuates bone cancer pain in a rat model. Mol. Pain 6:2. doi: 10.1186/1744-8069-6-2

Lewis, K. M., Harford-Wright, E., Vink, R., and Ghabriel, M. N. (2013). Characterisation of Walker 256 breast carcinoma cells from two tumour cell banks as assessed using two models of secondary brain tumours. Cancer Cell Int. 13:5. doi: 10.1186/1475-2867-13-5

Lewison, E. F. (1976). Spontaneous regression of breast cancer. Natl. Cancer Inst. Monogr. 44, 23-26.

Li, T. F., Fan, H., and Wang, Y. X. (2016). Aconitum-derived bulleyaconitine A exhibits antihypersensitivity through direct stimulating dynorphin A expression in spinal microglia. J. Pain 17, 530-548. doi: 10.1016/j.jpain.2015.12.015

Li, X., Li, G., Wu, S., Zhang, B., Wan, Q., Yu, D., et al. (2014). Antinociceptive effect of intrathecal microencapsulated human pheochromocytoma cell in a rat model of bone cancer pain. Int. J. Mol. Sci. 15, 12135-12148. doi: 10.3390/ijms150712135

Li, X., Wang, X. W., Feng, X. M., Zhou, W. J., Wang, Y. Q., and Mao-Ying, Q. L. (2013). Stage-dependent anti-allodynic effects of intrathecal Toll-like receptor 4 antagonists in a rat model of cancer induced bone pain. J. Physiol. Sci. 63, 203-209. doi: 10.1007/s12576-012-0244-5

Liscovitch, M., and Ravid, D. (2007). A case study in misidentification of cancer cell lines: MCF-7/AdrR cells (re-designated NCI/ADR-RES) are derived from 
OVCAR-8 human ovarian carcinoma cells. Cancer Lett. 245, 350-352. doi: 10.1016/j.canlet.2006.01.013

Liu, C., Song, J., Mao, Y., and Liu, X. (2015). Bone metastatic pain palliation in a modified rat bone cancer pain model using 188Re-HEDP therapy. J.Nucl. Med. 56(Suppl. 3), 1199.

Liu, S., Liu, W. T., Liu, Y. P., Dong, H. L., Henkemeyer, M., Xiong, L. Z., et al. (2011). Blocking EphB1 receptor forward signaling in spinal cord relieves bone cancer pain and rescues analgesic effect of morphine treatment in rodents. Cancer Res. 71, 4392-4402. doi: 10.1158/0008-5472.CAN-10-3870

Liu, S., Liu, Y. P., Song, W. B., and Song, X. J. (2013). EphrinB-EphB receptor signaling contributes to bone cancer pain via Toll-like receptor and proinflammatory cytokines in rat spinal cord. Pain 154, 2823-2835. doi: 10.1016/j.pain.2013.08.017

Liu, S., Yang, J., Wang, L., Jiang, M., Qiu, Q., Ma, Z., et al. (2010). Tibia tumorinduced cancer pain involves spinal p38 mitogen-activated protein kinase activation via TLR4-dependent mechanisms. Brain Res. 1346, 213-223. doi: 10.1016/j.brainres.2010.05.014

Liu, S., Zhang, M. Y., Chen, L. P., Liu, Y. P., and Liu, G. J. (2014). cGMP and cGMP-dependent protein kinase I pathway in dorsal root ganglia contributes to bone cancer pain in rats. Spine (Phila Pa 1976) 39, 1533-1541. doi: 10.1097/BRS.0000000000000456

Liu, X., Bu, H., Liu, C., Gao, F., Yang, H., Tian, X., et al. (2012). Inhibition of glial activation in rostral ventromedial medulla attenuates mechanical allodynia in a rat model of cancer-induced bone pain. J. Huazhong Univ. Sci. Technol. Med. Sci. 32, 291-298. doi: 10.1007/s11596-012-0051-5

Lozano-Ondoua, A. N., Symons-Liguori, A. M., and Vanderah, T. W. (2013). Cancer-induced bone pain: mechanisms and models. Neurosci. Lett. 557(Pt A), 52-59. doi: 10.1016/j.neulet.2013.08.003

Lu, C., Liu, Y., Sun, B., Sun, Y., Hou, B., Zhang, Y., et al. (2015). Intrathecal injection of JWH-015 attenuates bone cancer pain via time-dependent modification of pro-inflammatory cytokines expression and astrocytes activity in spinal cord. Inflammation 38, 1880-1890. doi: 10.1007/s10753-015-0168-3

Lu, C., Shi, L., Sun, B., Zhang, Y., Hou, B., Sun, Y., et al. (2016). A single intrathecal or intraperitoneal injection of $\mathrm{CB} 2$ receptor agonist attenuates bone cancer pain and induces a time-dependent modification of GRK2. Cell. Mol. Neurobiol. doi: 10.1007/s10571-016-0349-0. [Epub ahead of print].

Luty, M., Kwiecien, E., Firlej, M., Labedz-Maslowska, A., Paw, M., Madeja, Z., et al. (2016). Curcumin augments the cytostatic and anti-invasive effects of mitoxantrone on carcinosarcoma cells in vitro. Acta Biochim. Pol. doi: 10.18388/abp.2016_1314. [Epub ahead of print].

Ma, L., Perini, R., McKnight, W., Dicay, M., Klein, A., Hollenberg, M. D., et al. (2005). Proteinase-activated receptors 1 and 4 counter-regulate endostatin and VEGF release from human platelets. Proc. Natl. Acad. Sci. U.S.A. 102, 216-220. doi: 10.1073/pnas.0406682102

Mantyh, P. W., Clohisy, D. R., Koltzenburg, M., and Hunt, S. P. (2002). Molecular mechanisms of cancer pain. Nat. Rev. Cancer 2, 201-209. doi: 10.1038/nrc747

Mao-Ying, Q. L., Wang, X. W., Yang, C. J., Li, X., Mi, W. L., Wu, G. C., et al. (2012). Robust spinal neuroinflammation mediates mechanical allodynia in Walker 256 induced bone cancer rats. Mol. Brain 5:16. doi: 10.1186/1756-6606-5-16

Mao-Ying, Q. L., Zhao, J., Dong, Z. Q., Wang, J., Yu, J., Yan, M. F., et al. (2006). A rat model of bone cancer pain induced by intra-tibia inoculation of Walker 256 mammary gland carcinoma cells. Biochem. Biophys. Res. Commun. 345, 1292-1298. doi: 10.1016/j.bbrc.2006.04.186

Marx, V. (2014). Cell-line authentication demystified. Nat. Methods 11, 483-488. doi: $10.1038 /$ nmeth.2932

McEuen, C. S., and Thomson, D. L. (1933). The effect of hypophysectomy on the growth of the Walker rat tumour. Br. J. Exp. Pathol. 14, 384-391.

McKelvey, R., Berta, T., Old, E., Ji, R. R., and Fitzgerald, M. (2015). Neuropathic pain is constitutively suppressed in early life by antiinflammatory neuroimmune regulation. J. Neurosci. 35, 457-466. doi: 10.1523/JNEUROSCI.2315-14.2015

Medhurst, S. J., Walker, K., Bowes, M., Kidd, B. L., Glatt, M., Muller, M., et al. (2002). A rat model of bone cancer pain. Pain 96, 129-140. doi: 10.1016/S03043959(01)00437-7

Miao, X. R., Gao, X. F., Wu, J. X., Lu, Z. J., Huang, Z. X., Li, X. Q., et al. (2010). Bilateral downregulation of Nav1.8 in dorsal root ganglia of rats with bone cancer pain induced by inoculation with Walker 256 breast tumor cells. BMC Cancer 10:216. doi: 10.1186/1471-2407-10-216
Michaelson, S., and Orcutt, J. A. (1957). Observations on some growth characteristics of the Walker carcinoma 256. Cancer 10, 416-418.

Mogil, J. S. (2009). Animal models of pain: progress and challenges. Nat. Rev. Neurosci. 10, 283-294. doi: 10.1038/nrn2606

Mogil, J. S., and Grisel, J. E. (1998). Transgenic studies of pain. Pain 77, 107-128. doi: 10.1016/S0304-3959(98)00093-1

Muralidharan, A., Wyse, B. D., and Smith, M. T. (2013). Optimization and characterization of a rat model of prostate cancer-induced bone pain using behavioral, pharmacological, radiological, histological and immunohistochemical methods. Pharmacol. Biochem. Behav. 106, 33-46. doi: 10.1016/j.pbb.2013.02.020

Murphy, A. Z., Suckow, S. K., Johns, M., and Traub, R. J. (2009). Sex differences in the activation of the spinoparabrachial circuit by visceral pain. Physiol. Behav. 97, 205-212. doi: 10.1016/j.physbeh.2009.02.037

Nims, R. W., Sykes, G., Cottrill, K., Ikonomi, P., and Elmore, E. (2010). Short tandem repeat profiling: part of an overall strategy for reducing the frequency of cell misidentification. In Vitro Cell. Dev. Biol. Anim. 46, 811-819. doi: 10.1007/s11626-010-9352-9

North, R. A. (2002). Molecular physiology of P2X receptors. Physiol. Rev. 82, 1013-1067. doi: 10.1152/physrev.00015.2002

Oliveira, A. G., and Gomes-Marcondes, M. C. (2016). Metformin treatment modulates the tumour-induced wasting effects in muscle protein metabolism minimising the cachexia in tumour-bearing rats. BMC Cancer 16:418. doi: $10.1186 /$ s12885-016-2424-9

Onuigbo, W. I. (2012). Spontaneous regression of breast carcinoma: review of English publications from 1753 to 1897. Oncol. Rev. 6:e22. doi: 10.4081/oncol.2012.e22

Pacharinsak, C., and Beitz, A. (2008). Animal models of cancer pain. Comp. Med. 58, 220-233.

Pan, J., Lin, X.-J., Ling, Z.-H., and Cai, Y.-Z. (2015). Effect of down-regulation of voltage-gated sodium channel Nav1.7 on activation of astrocytes and microglia in DRG in rats with cancer pain. Asian Pac. J. Trop. Med. 8, 405-411. doi: 10.1016/S1995-7645(14)60352-7

Pan, R., Di, H., Zhang, J., Huang, Z., Sun, Y., Yu, W., et al. (2015). Inducible Lentivirus-Mediated siRNA against TLR4 Reduces Nociception in a Rat Model of Bone Cancer Pain. Mediators Inflamm. 2015:523896. doi: $10.1155 / 2015 / 523896$

Paqueron, X., Conklin, D., and Eisenach, J. C. (2003). Plasticity in action of intrathecal clonidine to mechanical but not thermal nociception after peripheral nerve injury. Anesthesiology 99, 199-204. doi: 10.1097/00000542200307000-00030

Pardoll, D. M., and Topalian, S. L. (1998). The role of CD4+ T cell responses in antitumor immunity. Curr. Opin. Immunol. 10, 588-594. doi: 10.1016/S09527915(98)80228-8

Pigatto, M. C., de Araujo, B. V., Torres, B. G., Schmidt, S., Magni, P., and Dalla Costa, T. (2016). Population pharmacokinetic modeling of etoposide free concentrations in solid tumor. Pharm. Res. 33, 1657-1670. doi: 10.1007/s11095016-1906-4

Poste, G., Doll, J., Brown, A. E., Tzeng, J., and Zeidman, I. (1982a). Comparison of the metastatic properties of B16 melanoma clones isolated from cultured cell lines, subcutaneous tumors, and individual lung metastases. Cancer Res. $42,2770-2778$

Poste, G., Tzeng, J., Doll, J., Greig, R., Rieman, D., and Zeidman, I. (1982b). Evolution of tumor cell heterogeneity during progressive growth of individual lung metastases. Proc. Natl. Acad. Sci. U.S.A. 79, 6574-6578.

Qiu, F., Jiang, Y., Zhang, H., Liu, Y., and Mi, W. (2012). Increased expression of tetrodotoxin-resistant sodium channels Nav1.8 and Nav1.9 within dorsal root ganglia in a rat model of bone cancer pain. Neurosci. Lett. 512, 61-66. doi: 10.1016/j.neulet.2012.01.069

Qiu, F., Wei, X., Zhang, S., Yuan, W., and Mi, W. (2014). Increased expression of acid-sensing ion channel 3 within dorsal root ganglia in a rat model of bone cancer pain. Neuroreport 25, 887-893. doi: 10.1097/WNR.0000000000000182

Qu, K., Zaba, L. C., Giresi, P. G., Li, R., Longmire, M., Kim, Y. H., et al. (2015). Individuality and variation of personal regulomes in primary human $\mathrm{T}$ cells. Cell Syst. 1, 51-61. doi: 10.1016/j.cels.2015.06.003

Rees, R. C., and Mian, S. (1999). Selective MHC expression in tumours modulates adaptive and innate antitumour responses. Cancer Immunol. Immunother. 48, 374-381. doi: 10.1007/s002620050589 
Ren, F., Jiao, H., and Cai, H. (2015). Analgesic effect of intrathecal administration of chemokine receptor CCR2 antagonist is related to change in spinal NR2B, nNOS, and SIGIRR expression in rat with bone cancer pain. Cell Biochem. Biophys. 72, 611-616. doi: 10.1007/s12013-014-0510-7

Sacchi, A., Mauro, F., and Zupi, G. (1984). Changes of phenotypic characteristics of variants derived from Lewis lung carcinoma during long-term in vitro growth. Clin. Exp. Metastasis 2, 171-178. doi: 10.1007/BF00052417

Saitoh, S., Akashi, S., Yamada, T., Tanimura, N., Matsumoto, F., Fukase, K., et al. (2004). Ligand-dependent Toll-like receptor 4 (TLR4)-oligomerization is directly linked with TLR4-signaling. J. Endotoxin Res. 10, 257-260. doi: 10.1177/09680519040100041001

Schaible, H. G. (2007). Peripheral and central mechanisms of pain generation. Handb. Exp. Pharmacol. 177, 3-28.

Schanoski, A. S., Cavalcanti, T. C., Campos, C. B., Viera-Matos, A. N., Rettori, O., and Guimarães, F. (2004). Walker 256 tumor MHC class I expression during the shift from A variant to the immunogenic AR variant. Cancer Lett. 211, 119-127. doi: 10.1016/j.canlet.2004.01.023

Schwab, J. M., and Serhan, C. N. (2006). Lipoxins and new lipid mediators in the resolution of inflammation. Curr. Opin. Pharmacol. 6, 414-420. doi: 10.1016/j.coph.2006.02.006

Schwei, M. J., Honore, P., Rogers, S. D., Salak-Johnson, J. L., Finke, M. P., Ramnaraine, M. L., et al. (1999). Neurochemical and cellular reorganization of the spinal cord in a murine model of bone cancer pain. J. Neurosci. 19, 10886-10897.

Seino, D., Tokunaga, A., Tachibana, T., Yoshiya, S., Dai, Y., Obata, K., et al. (2006). The role of ERK signaling and the P2X receptor on mechanical pain evoked by movement of inflamed knee joint. Pain 123, 193-203. doi: 10.1016/j.pain.2006.02.032

Serhan, C. N., and Savill, J. (2005). Resolution of inflammation: the beginning programs the end. Nat. Immunol. 6, 1191-1197. doi: 10.1038/ni1276

Sharma, G. N., Dave, R., Sanadya, J., Sharma, P., and Sharma, K. K. (2010). Various types and management of breast cancer: an overview. J. Adv. Pharm. Technol. Res. 1, 109-126.

Shen, W., Hu, X. M., Liu, Y. N., Han, Y., Chen, L. P., Wang, C. C., et al. (2014). CXCL12 in astrocytes contributes to bone cancer pain through CXCR4-mediated neuronal sensitization and glial activation in rat spinal cord. J. Neuroinflammation 11:75. doi: 10.1186/1742-2094-11-75

Shih, L. Y., Shih, H. N., and Chen, T. H. (2004). Bone resorption activity of osteolytic metastatic lung and breast cancers. J. Orthop. Res. 22, 1161-1167. doi: 10.1016/j.orthres.2003.03.004

Simmons, J. K., Hildreth, B. E., Supsavhad, W., Elshafae, S. M., Hassan, B. B., Dirksen, W. P., et al. (2015). Animal models of bone metastasis. Vet. Pathol. 52, 827-841. doi: 10.1177/0300985815586223

Simpkins, H., Lehman, J. M., Mazurkiewicz, J. E., and Davis, B. H. (1991). A morphological and phenotypic analysis of Walker 256 cells. Cancer Res. 51, 1334-1338.

Slosky, L. M., Largent-Milnes, T. M., and Vanderah, T. W. (2015). Use of animal models in understanding cancer-induced bone pain. Cancer Growth Metastasis 8(Suppl. 1), 47-62. doi: 10.4137/cgm.s21215

Smit, M. J., Verdijk, P., van der Raaij-Helmer, E. M. H., Navis, M., Hensbergen, P. J., Leurs, R., et al. (2003). CXCR3-mediated chemotaxis of human T cells is regulated by a Gi- and phospholipase C-dependent pathway and not via activation of MEK/p44/p42 MAPK nor Akt/PI-3 kinase. Blood 102, 1959-1965. doi: 10.1182/blood-2002-12-3945

Song, H., Han, Y., Pan, C., Deng, X., Dai, W., Hu, L., et al. (2015). Activation of adenosine monophosphate-activated protein kinase suppresses neuroinflammation and ameliorates bone cancer pain: involvement of inhibition on mitogen-activated protein kinase. Anesthesiology 123, 1170-1185. doi: 10.1097/ALN.0000000000000856

Song, Z. P., Xiong, B. R., Guan, X. H., Cao, F., Manyande, A., Zhou, Y. Q., et al. (2016). Minocycline attenuates bone cancer pain in rats by inhibiting NF-kappaB in spinal astrocytes. Acta Pharmacol. Sin. 37, 753-762. doi: 10.1038/aps.2016.1

Sorge, R. E., Mapplebeck, J. C. S., Rosen, S., Beggs, S., Taves, S., Alexander, J. K., et al. (2015). Different immune cells mediate mechanical pain hypersensitivity in male and female mice. Nat. Neurosci. 18, 1081-1083. doi: 10.1038/nn.4053

Sorge, R. E., Martin, L. J., Isbester, K. A., Sotocinal, S. G., Rosen, S., Tuttle, A. H., et al. (2014). Olfactory exposure to males, including men, causes stress and related analgesia in rodents. Nat. Methods 11, 629-632. doi: 10.1038/nmeth.2935

Sroka, J., Krecioch, I., Zimolag, E., Lasota, S., Rak, M., Kedracka-Krok, S., et al. (2016). Lamellipodia and membrane blebs drive efficient electrotactic migration of rat Walker carcinosarcoma cells WC 256. PLoS ONE 11:e0149133. doi: 10.1371/journal.pone.0149133

Taché, Y., and Million, M. (2015). Role of corticotropin-releasing factor signaling in stress-related alterations of colonic motility and hyperalgesia. J. Neurogastroenterol. Motil. 21, 8-24. doi: 10.5056/jnm14162

Toneto, A. T., Ferreira Ramos, L. A., Salomão, E. M., Tomasin, R., Aereas, M. A., and Gomes-Marcondes, M. C. (2016). Nutritional leucine supplementation attenuates cardiac failure in tumour-bearing cachectic animals. J. Cachexia Sarcopenia Muscle. doi: 10.1002/jcsm.12100. [Epub ahead of print].

Tong, W., Wang, W., Huang, J., Ren, N., Wu, S. X., and Li, Y. Q. (2010). Spinal high-mobility group box 1 contributes to mechanical allodynia in a rat model of bone cancer pain. Biochem. Biophys. Res. Commun. 395, 572-576. doi: 10.1016/j.bbrc.2010.04.086

Trashkov, A. P., Vasil'ev, A. G., Kovalenko, A. L., Petrov, A. Y., and Valeev, V. V. (2016). [Influence of angioprotector drugs on the efficacy of cytostatic therapy (experimental study)]. Eksp. Klin. Farmakol. 79, 34-39.

Tuttle, A. H., Tohyama, S., Ramsay, T., Kimmelman, J., Schweinhardt, P., Bennett, G. J., et al. (2015). Increasing placebo responses over time in U.S. clinical trials of neuropathic pain. Pain 156, 2616-2626. doi: 10.1097/j.pain.0000000000000333

Urch, C. (2004). The pathophysiology of cancer-induced bone pain: current understanding. Palliat. Med. 18, 267-274. doi: 10.1191/0269216304pm887ra

Vacca, V., Marinelli, S., Pieroni, L., Urbani, A., Luvisetto, S., and Pavone, F. (2014). Higher pain perception and lack of recovery from neuropathic pain in females: a behavioural, immunohistochemical, and proteomic investigation on sexrelated differences in mice. Pain 155, 388-402. doi: 10.1016/j.pain.2013.10.027

Vacca, V., Marinelli, S., Pieroni, L., Urbani, A., Luvisetto, S., and Pavone, F. (2016). 17beta-estradiol counteracts neuropathic pain: a behavioural, immunohistochemical, and proteomic investigation on sex-related differences in mice. Sci. Rep. 6:18980. doi: 10.1038/srep18980

Walker, K., Fox, A. J., and Urban, L. A. (1999). Animal models for pain research. Mol. Med. Today 5, 319-321. doi: 10.1016/S1357-4310(99)01493-8

Walpole, A. L. (1951). The Walker carcinoma 256 in the screening of tumour inhibitors. Br. J. Pharmacol. Chemother. 6, 135-143. doi: 10.1111/j.14765381.1951.tb00629.x

Wang, J., Zhang, R., Dong, C., Jiao, L., Xu, L., Liu, J., et al. (2012). Topical treatment with Tong-Luo-San-Jie gel alleviates bone cancer pain in rats. J. Ethnopharmacol. 143, 905-913. doi: 10.1016/j.jep.2012.08.026

Wang, J., Zhang, R., Dong, C., Jiao, L., Xu, L., Liu, J., et al. (2015). Transient receptor potential channel and interleukin-17A involvement in LTTL gel inhibition of bone cancer pain in a rat model. Integr. Cancer Ther. 14, 381-393. doi: $10.1177 / 1534735415580677$

Wang, L. N., Yang, J. P., Ji, F. H., Zhan, Y., Jin, X. H., Xu, Q. N., et al. (2012a). Brain-derived neurotrophic factor modulates $\mathrm{N}$-methyl-D-aspartate receptor activation in a rat model of cancer-induced bone pain. J. Neurosci. Res. 90, 1249-1260. doi: 10.1002/jnr.22815

Wang, L. N., Yang, J. P., Zhan, Y., Ji, F. H., Wang, X. Y., Zuo, J. L., et al. (2012b). Minocycline-induced reduction of brain-derived neurotrophic factor expression in relation to cancer-induced bone pain in rats. J. Neurosci. Res. 90, 672-681. doi: 10.1002/jnr.22788

Wang, L. N., Yao, M., Yang, J. P., Peng, J., Peng, Y., Li, C. F., et al. (2011). Cancerinduced bone pain sequentially activates the ERK/MAPK pathway in different cell types in the rat spinal cord. Mol. Pain 7:48. doi: 10.1186/1744-8069-7-48

Wang, X. W., Hu, S., Mao-Ying, Q. L., Li, Q., Yang, C. J., Zhang, H., et al. (2012a). Activation of c-jun N-terminal kinase in spinal cord contributes to breast cancer induced bone pain in rats. Mol. Brain 5:21. doi: 10.1186/1756-66 06-5-21

Wang, X. W., Li, T. T., Zhao, J., Mao-Ying, Q. L., Zhang, H., Hu, S., et al. (2012b). Extracellular signal-regulated kinase activation in spinal astrocytes and microglia contributes to cancer-induced bone pain in rats. Neuroscience 217, 172-181. doi: 10.1016/j.neuroscience.2012.04.065

Wang, Z. L., Du, T. T., and Zhang, R. G. (2016). JNK in spinal cord facilitates bone cancer pain in rats through modulation of CXCL1. J. Huazhong Univ. Sci. Technol. Med. Sci. 36, 88-94. doi: 10.1007/s11596-016-1547-1 
Webb, T. E., Simon, J., Bateson, A. N., and Barnard, E. A. (1994). Transient expression of the recombinant chick brain P2y1 purinoceptor and localization of the corresponding mRNA. Cell. Mol. Biol. (Noisy-le-grand). 40, 437-442.

Wiesenfeld-Hallin, Z. (2005). Sex differences in pain perception. Gend. Med. 2, 137-145. doi: 10.1016/S1550-8579(05)80042-7

Wilson, S. G., and Mogil, J. S. (2001). Measuring pain in the (knockout) mouse: big challenges in a small mammal. Behav. Brain Res. 125, 65-73. doi: 10.1016/S0166-4328(01)00281-9

Wu, J. X., Xu, M. Y., Miao, X. R., Lu, Z. J., Yuan, X. M., Li, X. Q., et al. (2012). Functional up-regulation of $\mathrm{P} 2 \mathrm{X} 3$ receptors in dorsal root ganglion in a rat model of bone cancer pain. Eur. J. Pain 16, 1378-1388. doi: 10.1002/j.15322149.2012.00149.x

Wu, J. X., Yuan, X. M., Wang, Q., Wei, W., and Xu, M. Y. (2016). Rho/ROCK acts downstream of lysophosphatidic acid receptor 1 in modulating P2X3 receptor-mediated bone cancer pain in rats. Mol. Pain 12:1744806916644929. doi: $10.1177 / 1744806916644929$

Wu, M., Lu, L., Zhang, Q., Guo, Q., Zhao, F., Li, T., et al. (2016). Relating doses of contrast agent administered to tic and semi-quantitative parameters on DCEMRI: based on a murine breast tumor model. PLOS ONE 11:e0149279. doi: 10.1371/journal.pone.0149279

Xia, H., Zhang, D., Yang, S., Wang, Y., Xu, L., Wu, J., et al. (2014). Role of ATPsensitive potassium channels in modulating nociception in rat model of bone cancer pain. Brain Res. 1554, 29-35. doi: 10.1016/j.brainres.2014.01.032

Xu, J.-Y., Jiang, Y., Liu, W., and Huang, Y.-G. (2015). Calpain inhibitor reduces cancer-induced bone pain possibly through inhibition of osteoclastogenesis in rat cancer-induced bone pain model. Chin. Med. J. (Engl). 128, 1102-1107. doi: 10.4103/0366-6999.155109

Xu, Q., Zhang, X. M., Duan, K. Z., Gu, X. Y., Han, M., Liu, B. L., et al. (2013). Peripheral TGF-betal signaling is a critical event in bone cancer-induced hyperalgesia in rodents. J. Neurosci. 33, 19099-19111. doi: 10.1523/JNEUROSCI.4852-12.2013

Yalovenko, T. M., Todor, I. M., Lukianova, N. Y., and Chekhun, V. F. (2016). Hepcidin as a possible marker in determination of malignancy degree and sensitivity of breast cancer cells to cytostatic drugs. Exp. Oncol. 38, 84-88.

Yang, Y., Li, H., Li, T. T., Luo, H., Gu, X. Y., Lü, N., et al. (2015). Delayed activation of spinal microglia contributes to the maintenance of bone cancer pain in female Wistar rats via P2X7 receptor and IL-18. J. Neurosci. 35, 7950-7963. doi: 10.1523/JNEUROSCI.5250-14.2015

Yao, M., Yang, J. P., Wang, L. N., Cheng, H., Zhang, Y. B., Xu, Q. N., et al. (2008). [Feasibility of establishment of rat model of bone cancer pain by using Walker 256 cells cultured in vitro or in vivo]. Zhonghua Yi Xue Za Zhi 88, 880-884.

Yao, P., Ding, Y., Wang, Z., Ma, J., Hong, T., Zhu, Y., et al. (2016). Impacts of anti-nerve growth factor antibody on pain-related behaviors and expressions of opioid receptor in spinal dorsal horn and dorsal root ganglia of rats with cancerinduced bone pain. Mol. Pain 12:1744806916644928. doi: 10.1177/17448069166 44928

Ye, D., Bu, H., Guo, G., Shu, B., Wang, W., Guan, X., et al. (2014). Activation of CXCL10/CXCR3 signaling attenuates morphine analgesia: involvement of Gi protein. J. Mol. Neurosci. 53, 571-579. doi: 10.1007/s12031-0130223-1

Yin, Q., Cheng, W., Cheng, M. Y., Fan, S. Z., and Shen, W. (2010). Intrathecal injection of anti-CX3CR1 neutralizing antibody delayed and attenuated pain facilitation in rat tibial bone cancer pain model. Behav. Pharmacol. 21, 595-601. doi: 10.1097/FBP.0b013e32833e7e2a
Yu, S., Peng, H. D., Ju, D. W., Wei, P. K., Xu, L., Lao, L. X., et al. (2009). Mechanisms of treatment of cancer pain with a topical Chinese herbal formula in rats. Chin. Med. J. 122, 2027-2031.

Yung, Y. C., Stoddard, N. C., and Chun, J. (2014). LPA receptor signaling: pharmacology, physiology, and pathophysiology. J. Lipid Res. 55, 1192-1214. doi: 10.1194/jlr.R046458

Zhang, J. Y., Gong, N., Huang, J. L., Guo, L. C., and Wang, Y. X. (2013). Gelsemine, a principal alkaloid from Gelsemium sempervirens Ait., exhibits potent and specific antinociception in chronic pain by acting at spinal alpha3 glycine receptors. Pain 154, 2452-2462. doi: 10.1155/2015/752512

Zhang, M. Y., Liu, Y. P., Zhang, L. Y., Yue, D. M., Qi, D. Y., Liu, G. J., et al. (2015). Levo-tetrahydropalmatine attenuates bone cancer pain by inhibiting microglial cells activation. Mediators Inflamm. 2015:752512. doi: 10.1155/2015/752512

Zhao, J., Pan, H. L., Li, T. T., Zhang, Y. Q., Wei, J. Y., and Zhao, Z. Q. (2010). The sensitization of peripheral C-fibers to lysophosphatidic acid in bone cancer pain. Life Sci. 87, 120-125. doi: 10.1016/j.lfs.2010.05.015

Zhao, Q., Zhang, L., Shu, R., Wang, C., Yu, Y., Wang, H., et al. (2016). Involvement of spinal PKMzeta expression and phosphorylation in remifentanil-induced long-term hyperalgesia in rats. Cell. Mol. Neurobiol. doi: 10.1007/s10571-0160401-0. [Epub ahead of print].

Zhao, Y., Tian, L., Sheng, W., Miao, J., and Yang, J. (2013). Hypalgesia effect of IL-24, a quite new mechanism for IL-24 application in cancer treatment. J. Interferon Cytokine Res. 33, 606-611. doi: 10.1089/jir.2012.0146

Zhou, Y. L., Jiang, G. Q., Wei, J., Zhang, H. H., Chen, W., Zhu, H., et al. (2015). Enhanced binding capability of nuclear factor-kappaB with demethylated P2X3 receptor gene contributes to cancer pain in rats. Pain 156, 1892-1905. doi: 10.1097/j.pain.0000000000000248

Zhu, B., Gong, N., Fan, H., Peng, C. S., Ding, X. J., Jiang, Y., et al. (2014). Lamiophlomis rotata, an orally available Tibetan herbal painkiller, specifically reduces pain hypersensitivity states through the activation of spinal glucagon-like peptide-1 receptors. Anesthesiology 121, 835-851. doi: 10.1097/aln.0000000000000320

Zhu, G., Dong, Y., He, X., Zhao, P., Yang, A., Zhou, R., et al. (2016). Radiotherapy suppresses bone cancer pain through inhibiting activation of camp signaling in rat dorsal root ganglion and spinal cord. Mediators Inflamm. 2016:5093095. doi: 10.1155/2016/5093095

Zhu, G. Q., Liu, S., He, D. D., Liu, Y. P., and Song, X. J. (2014). Activation of the cAMP-PKA signaling pathway in rat dorsal root ganglion and spinal cord contributes toward induction and maintenance of bone cancer pain. Behav. Pharmacol. 25, 267-276. doi: 10.1097/fbp.0000000000000048

Zhu, S., Wang, C., Han, Y., Song, C., Hu, X., and Liu, Y. (2015). Sigma-1 receptor antagonist bd 1047 reduces mechanical allodynia in a rat model of bone cancer pain through the inhibition of spinal nrl phosphorylation and microglia activation. Mediators Inflamm. 2015, 4239-4245. doi: 10.1155/2015/265056

Conflict of Interest Statement: The authors declare that the research was conducted in the absence of any commercial or financial relationships that could be construed as a potential conflict of interest.

Copyright (c) 2016 Shenoy, Kuo, Vetter and Smith. This is an open-access article distributed under the terms of the Creative Commons Attribution License (CC BY). The use, distribution or reproduction in other forums is permitted, provided the original author(s) or licensor are credited and that the original publication in this journal is cited, in accordance with accepted academic practice. No use, distribution or reproduction is permitted which does not comply with these terms. 